Safeguards-by-Design:

Guidance for

High Temperature Gas Reactors

(HTGRs)

With Pebble Fuel

Philip Casey Durst

August 2012

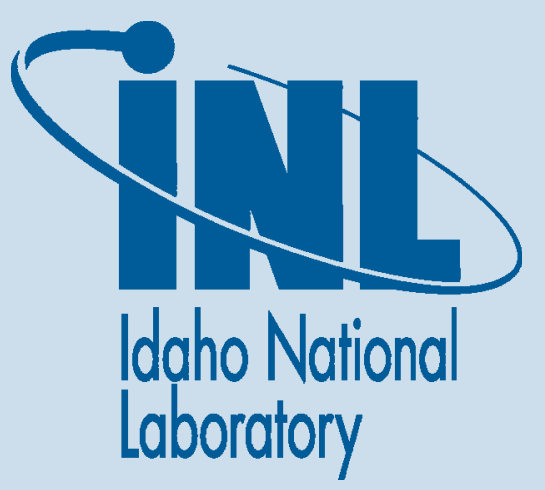




\section{DISCLAIMER}

This information was prepared as an account of work sponsored by an agency of the U.S. Government. Neither the U.S. Government nor any agency thereof, nor any of their employees, makes any warranty, expressed or implied, or assumes any legal liability or responsibility for the accuracy, completeness, or usefulness, of any information, apparatus, product, or process disclosed, or represents that its use would not infringe privately owned rights. References herein to any specific commercial product, process, or service by trade name, trade mark, manufacturer, or otherwise, does not necessarily constitute or imply its endorsement, recommendation, or favoring by the U.S. Government or any agency thereof. The views and opinions of authors expressed herein do not necessarily state or reflect those of the U.S. Government or any agency thereof. 


\title{
Safeguards-by-Design: \\ Guidance for High Temperature Gas Reactors (HTGRs) \\ With Pebble Fuel
}

\author{
Philip Casey Durst
}

August 2012

Idaho National Laboratory Nuclear Nonproliferation Division

Idaho Falls, Idaho 83415

http://www.inl.gov

\author{
Prepared for the \\ National Nuclear Security Administration \\ Office of NA-24 \\ and for the \\ U.S. Department of Energy \\ Under DOE Idaho Operations Office \\ Contract DE-AC07-05ID14517
}




\section{ACKNOWLEDGEMENTS}

Funding for the preparation of this document was provided by the U.S. DOE NNSA Office of Nonproliferation and International Security (NA-24), under the Safeguards-byDesign (SBD) Project, and in support of the NNSA Next Generation Safeguards Initiative. We wish to thank the Office of NA-24 for their support, input, and guidance in preparing this document. 


\section{CONTENTS}

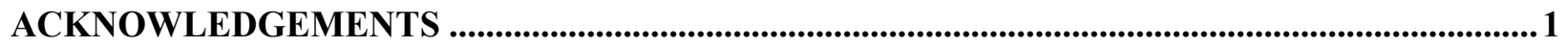

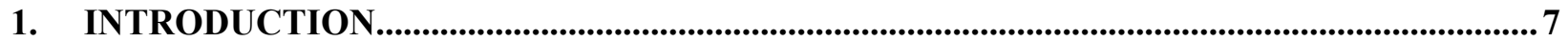

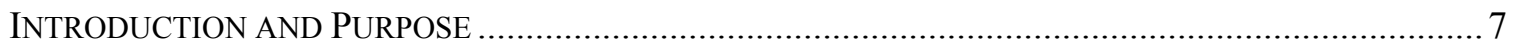

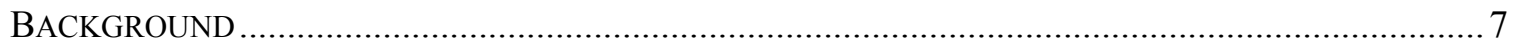

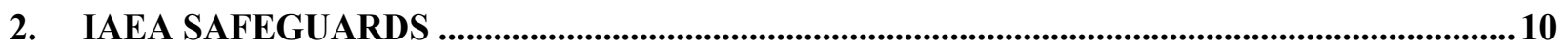

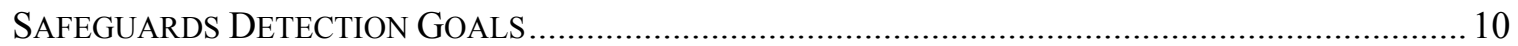

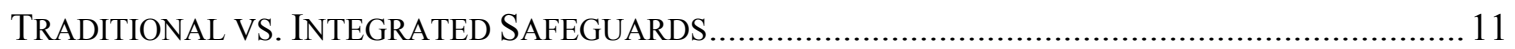

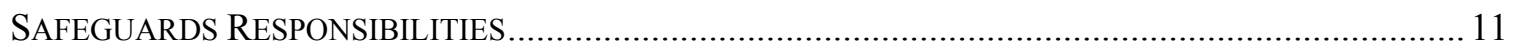

3. ELEMENTS OF DESIGN RELEVANT TO SAFEGUARDS................................................... 12

NuClEAR MATERIAL BALANCE AREAS AND KEY MEASUREMENT POINTS................................. 12

SAFEGUARDS STRATEGY AND POSSIBLE DIVERSION SCENARIOS ................................................ 14

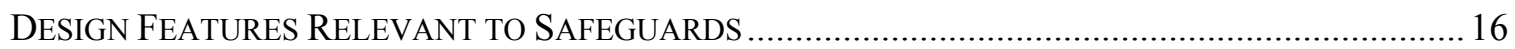

4. KEY ELEMENTS OF SAFEGUARDS STRATEGY/APPROACH........................................ 17

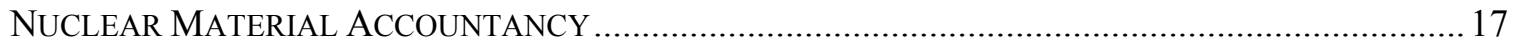

VERIFICATION OF FRESH PEBBLE FUEL RECEIPTS AND INVENTORY ......................................... 18

VERIFICATION OF PEBBLE FUEL IN THE CORE AND ASSOCIATED TRANSFERS.............................. 18

VERIFICATION OF SPENT PEBBLE FUEL INVENTORY AND SHIPMENTS...................................... 19

DETECTION OF POTENTIAL FACILITY MiSUSE (INCLUDING UNDECLARED ACTIVITIES) .............. 19

DETECTION OF NUCLEAR MATERIAL BORROWING ............................................................... 19

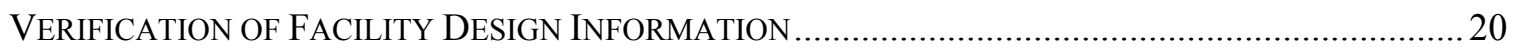

5. SAFEGUARDS BEST PRACTICES RELEVANT TO THE DESIGN.......................................20

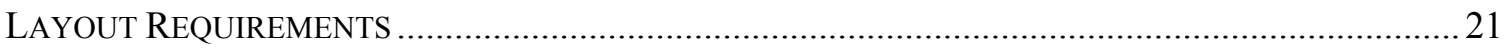

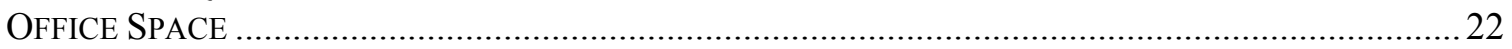

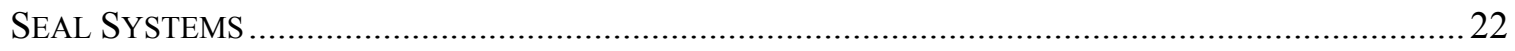

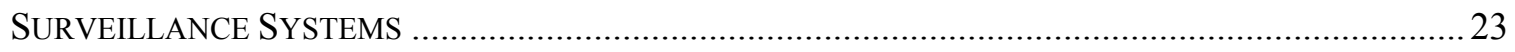

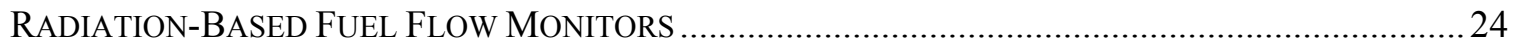

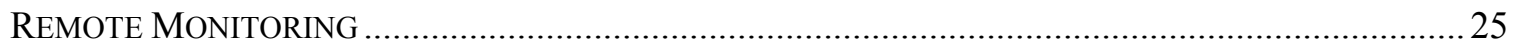

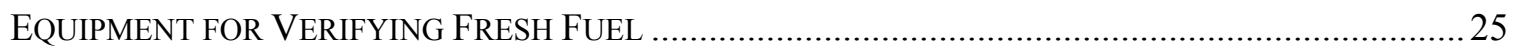

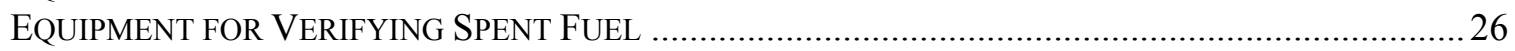

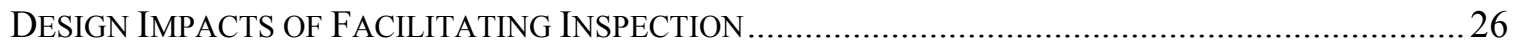

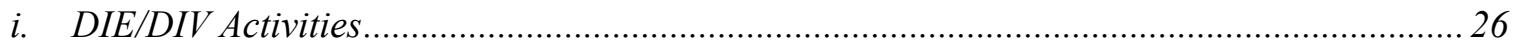

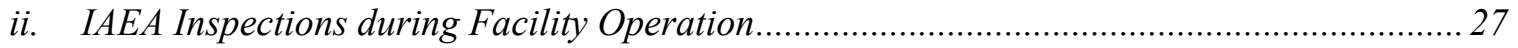

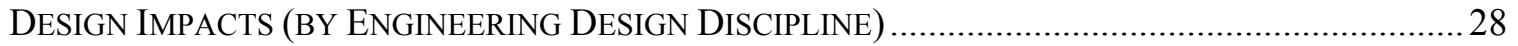

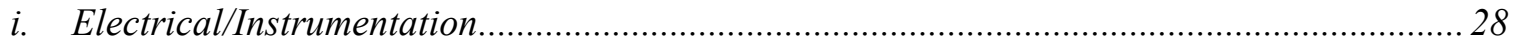

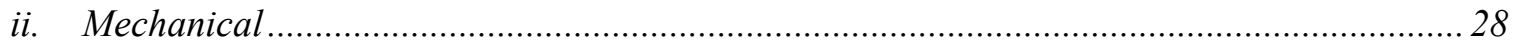

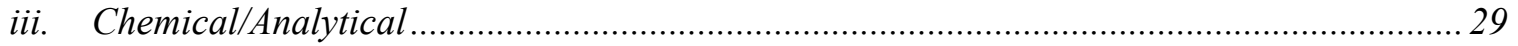

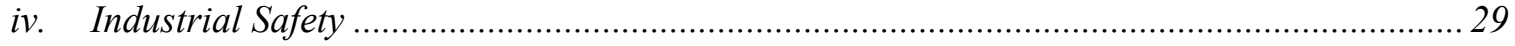

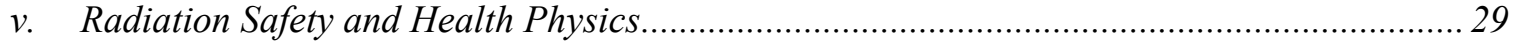

APPENDIX - EMERGING TECHNOLOGIES ...........................................................................................30

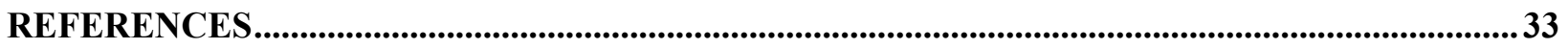




\section{FIGURES}

Figure-1: Typical Material Balance Area (MBA) Layout and Key Measurement Points (KMPs) for a

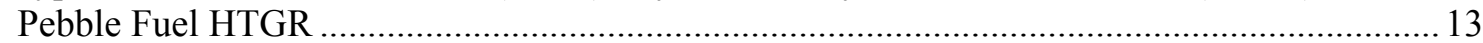

Figure-2: Typical Layout of IAEA Safeguards Equipment for a Pebble Fuel HTGR ..............................21

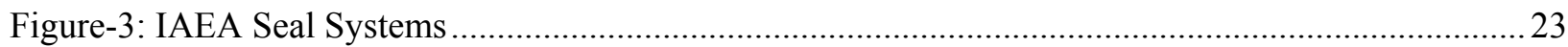

Figure-4: IAEA Next Generation Surveillance Camera and System (NGSS) ........................................2 24

Figure-5: Radiation-Based Fuel Flow Monitoring System and Components .........................................25

\section{TABLES}

Table-I: Major High Temperature Reactor Projects Worldwide 9 


\section{LIST OF ACRONYMS AND ABBREVIATIONS}

3DLR (IAEA) 3-Dimensional Laser Range Finder

AFR

(IAEA) Away-From-Reactor Storage Facility for spent fuel, also known as an ISFSI

ALARA As Low as Reasonably Achievable (radiation exposure guidelines)

Amp

Amperes (electrical current)

AP

(IAEA) Additional Protocol (see also INFCIRC/540)

AWCC

(IAEA) Active Well Coincidence Counter

BARC

Bhabha Atomic Research Centre (India)

BISO

Bi-layer coating for fuel particles used in high temperature reactors

BOG

IAEA Board of Governors

$\mathrm{CA}$

(IAEA) Complementary Access (under the Additional Protocol)

CAPS

(IAEA) Metal cap and wire seal

CNEC

China Nuclear Energy and Construction Group (CNEC)

$\mathrm{cm}$

Centimeters

DC

Direct Current

DCVD

Digital Cerenkov Viewing Device

DIE

(IAEA) Design Information Examination

DIQ

(IAEA) Design Information Questionnaire

DIV

(IAEA) Design Information Verification

DOE U. S. Department of Energy

EOSS (IAEA) Next Generation Electro-Optical Sealing System

ES

(IAEA) Environmental (Swipe) Sampling

HEU

Highly Enriched Uranium (U-235 $\geq 20 \%$ )

HM-5 (IAEA) Hand-held Radiation Meter Model \#5

HRGS (IAEA) High Resolution Gamma Spectrometer

HTGR High Temperature Gas Reactor (generic)

HTR High Temperature Reactor (includes gas and liquid metal cooled)

HTTR (JAERI) High Temperature Test Reactor

$\mathrm{Hz} \quad$ Hertz (cycles per second)

IAEA International Atomic Energy Agency

ICVD Improved Cerenkov Viewing Device

ID Identification

INFCIRC/66 (IAEA) Early Safeguards Agreement (now limited to India, Israel, and Pakistan)

INFCIRC/153 (IAEA) Model Comprehensive Safeguards Agreement 
INFCIRC/540 (IAEA) Model Additional Protocol

ISFSI (U.S. DOE/NRC) Independent Spent Fuel Storage Installation, also known as AFR Storage Facility

JAERI/JAEA Japan Atomic Energy Research Institute/Japan Atomic Energy Agency

KMP Key Measurement Point (nuclear material flow or inventory)

LCBS (IAEA) Load Cell Balance System

LEU Low Enriched Uranium $(0.7 \%<\mathrm{U}-235<20 \%)$

LOF (IAEA) Location Outside Facilities

LWR Light Water Reactor

m Meter

MBA Nuclear Material Balance Area

MMCC (IAEA) Mini Multi-Channel Analyzer with CdTe probe

MOX Mixed Plutonium/Uranium Oxide

MWe Megawatts, Electrical Output

MWth Megawatts, Thermal Power Output

NDA Non-Destructive Assay

NGAM (IAEA) Next Generation ADAM (radiation detector data collection module)

NGNP (U.S. DOE) Next Generation Nuclear Plant

NGSI (U.S. DOE/NNSA) Next Generation Safeguards Initiative

NGSS (IAEA) Next Generation Surveillance System

NNSA (U. S. DOE) National Nuclear Security Administration

NPT Treaty on the Non-Proliferation of Nuclear Weapons

NRC U.S. Nuclear Regulatory Commission

ORIGEN Oak Ridge spent fuel burn-up code

PBMR Pebble Bed Modular Reactor (a pebble fuel HTGR)

PIE Post Irradiation Examination

PNCL (IAEA) Plutonium Neutron Coincidence Collar

$\mathrm{Pu} \quad$ Plutonium, chemical symbol

RF Radio Frequency

RMSA (Canberra/AREVA) Remotely Monitored Sealing Array

RRC Russian Research Center (formerly Kurchatov Institute, Russia)

RSD Random Standard Deviation

SBD (NNSA) Safeguards-by-Design

SNRI (IAEA) Short-Notice Random Inspection

SQ (IAEA) Significant Quantity of Fissile Material 
SSAC State System of Accounting for and Control of Nuclear Material, (a function performed by the State Regulatory Authority)

Th Thorium, chemical symbol

TRISO Tri-layer coating for fuel particles used in high temperature reactors

U Uranium, chemical symbol

U-233 Uranium Fissile Isotope, produced from irradiating thorium

U-235 Uranium Fissile Isotope, naturally occurring but can be enriched to produce LEU and HEU

UPS Uninterruptible Power Supply

VAC Volts, Alternating Current

VACOS (IAEA) Variable-Coded Sealing System 


\section{Safeguards-by-Design:}

Guidance for

\section{High Temperature Gas Reactors (HTGRs) With Pebble Fuel 1. INTRODUCTION}

\section{Introduction and Purpose}

This document is part of a series of guidance documents developed by the National Nuclear Security Administration's Next Generation Safeguards Initiative to assist facility designers and operators in implementing international Safeguards-by-Design (SBD). SBD has two main objectives: (1) to avoid costly and time consuming redesign work or retrofits of new nuclear fuel cycle facilities and (2) to make the implementation of international safeguards more effective and efficient at such facilities. In the long term, the attainment of these goals would save both industry and the International Atomic Energy Agency (IAEA) time, money, and resources - a mutually beneficial win-win endeavor. This particular safeguards guidance document focuses on pebble fuel high temperature gas reactors (HTGRs).

The purpose of the IAEA safeguards system is to provide credible assurance to the international community that nuclear material and other specified items are not diverted from peaceful nuclear uses. ${ }^{1}$ The safeguards system consists of the IAEA's statutory authority to establish safeguards, safeguards rights and obligations in safeguards agreements and additional protocols, and technical measures implemented pursuant to those agreements. Of foremost importance as a basis for IAEA safeguards is the international safeguards agreement between the country and the IAEA, concluded pursuant to the Treaty on the Non-Proliferation of Nuclear Weapons (NPT).

According to a 1992 IAEA Board of Governors decision, countries must: notify the IAEA of a decision to construct a new nuclear facility as soon as such decision is taken; provide design information on such facilities as the designs develop; and provide detailed design information (called a "Design Information Questionnaire" in IAEA parlance) based on construction plans at least 180 days prior to the start of construction, and on "as-built" designs at least 180 days before the first receipt of nuclear material. ${ }^{2}$ Since the main interlocutor with the IAEA in each country is a State Regulatory Authority or Regional Regulatory Authority (e.g. EURATOM), the responsibility for transferring this design information falls to the State Regulatory Authority.

For the nuclear industry to reap the benefits of SBD (i.e., avoided costs and averted schedule slippages), designers/operators should work closely with the State Regulatory Authority and IAEA as soon as a decision is taken to build a new nuclear facility. Ideally, this interaction should begin during the conceptual design phase and continue throughout construction and start-up of a nuclear facility. Such early coordination and planning could influence decisions on, for example, the chemical processing flowsheet and design, the material storage and handling arrangements, and the facility layout.

Communication among the designer, facility operator, State Regulatory Authority, and IAEA should be frequent and iterative throughout facility design, construction, and start-up. This dialog will help to more effectively and efficiently incorporate IAEA safeguards into the design of nuclear facilities and to minimize misunderstandings that could arise from misinterpretation of the safeguards input and guidance.

\section{Background}

Nuclear facility designers, operators, electrical utilities, and government nuclear R\&D organizations have looked to the promise of HTGRs since the early days of nuclear power development in the 1950s. Because the fuel is made to endure high operating temperatures without melting $\left(>900{ }^{\circ} \mathrm{C}\right)$, HTGRs have a much better overheating safety margin than current LWRs, are effectively melt-down proof, and are 
more thermodynamically efficient than current light water reactors (LWRs) (i.e. they produce more electricity per given watt of thermal power output). For these reasons, the U.S. DOE is planning on the Next Generation Nuclear Plant (NGNP) being an HTGR. ${ }^{3,4}$ Major global high temperature reactor projects are listed in Table-I, showing historic milestones, as well as countries pursuing this reactor type for possible deployment in the future. ${ }^{5,6,7,8,9}$ The majority of these designs are helium gas-cooled reactors, and a significant percentage are pebble fuel HTGRs - a variant of which is the pebble bed modular reactor (PBMR).

The fuel for the HTGR is of two fundamental types. The nuclear fuel seeds or kernels in both cases are very small, approximately $0.5 \mathrm{~mm}$ in diameter. The kernels typically consist of uranium dioxide enriched in U-235 (between 3\% and 19\%), but may also contain plutonium and/or thorium, which are coated with high temperature silicon carbide and pyrolytic graphite. In one case, these kernels are embedded in a tennis-ball sized pyrolytic graphite matrix, which is termed a fuel "pebble." In the other case, the coated fuel kernels are pressed and sintered into cylindrical fuel compacts (like fuel pellets), which are loaded into graphite sleeves, and then into larger hexagonal (prismatic shaped) assemblies. ${ }^{10,11}$ Consequently, the two fundamental HTGR types are those using pebble-fuel and those using prismaticshaped assemblies. This safeguards design guidance document addresses the pebble fuel HTGR in particular. A companion document in this series provides safeguards design guidance for the prismatic fuel HTGR.

From a nuclear safeguards standpoint, key differences between the pebble fuel HTGR and an LWR (as a point of reference) are:

- The pebble fuel HTGR is an on-load refueled reactor, and in this respect is more akin to the Canadian Deuterium/Uranium (CANDU) reactor

- The pebble fuel assemblies are more small and numerous, and consequently are more challenging to count due to the greater number in the core (several hundred thousand)

- Start up of the pebble fuel HTGR core requires an initial loading of graphite moderator pebbles, which are drawn down as the reactor reaches nuclear equilibrium

- Verifying pebble fuel and distinguishing it from pebble moderator is a new safeguards issue

- After the pebble fuel HTGR reaches nuclear equilibrium, spent fuel is continuously removed and fresh fuel transferred to the core to take its place

- The flow of fuel to and from the pebble fuel HTGR core follows a more elaborate flow scheme and requires greater attention in monitoring fuel transfers, because the pebble fuel is smaller and the movements concealed below the reactor building floor

- Because of the greater number of inventory and flow key measurement points (KMP), the pebble fuel HTGR requires containment and surveillance measures at more locations (relative to an LWR).

The latter point is discussed in more detail in Section-3.

Another aspect is that most pebble fuel HTGR designs are modular. Consequently, groups of reactor core modules may be collocated in a facility to meet a variety of customer power and process heat needs, from medium to large-scale (i.e. 400 to $3000 \mathrm{MWth}$ ). The safeguards measures (e.g. seals, cameras, and radiation detectors) used to monitor the fuel storage areas and core would need to be replicated for multiple core and fuel storage areas. The safeguards impact of these various issues will be discussed in more detail. 


\begin{tabular}{|c|c|c|c|c|}
\hline \multicolumn{5}{|c|}{$\begin{array}{l}\text { Table-I: Major High Temperature Reactor Projects Worldwide } \\
\text { (Source: Durst Nuclear Engineering and Consulting Inc., 2012) }\end{array}$} \\
\hline Item & Reactor \& Developers & Country & Type \& Power Output & Status \\
\hline 1 & $\begin{array}{l}\text { Next Generation Nuclear Plant } \\
\text { (NGNP); U.S. DOE \& NGNP } \\
\text { Industry Alliance }\end{array}$ & $\begin{array}{l}\text { USA \& } \\
\text { International } \\
\text { Partners }\end{array}$ & $\begin{array}{l}\text { Prismatic fuel HTGR, } \\
3000 \text { MWth (1025 MWe) }\end{array}$ & $\begin{array}{l}\text { Design Phase, start-up } \\
\text { planned for ca. } 2025\end{array}$ \\
\hline 2 & $\begin{array}{l}\text { Pebble Bed Modular Reactor } \\
\text { (PBMR); PBMR (Pty) Ltd. \& } \\
\text { Toshiba/Westinghouse Partners }\end{array}$ & $\begin{array}{l}\text { South Africa \& } \\
\text { International } \\
\text { Partners }\end{array}$ & $\begin{array}{l}\text { Pebble fuel HTGR, } \\
180 \text { MWe per module }\end{array}$ & Design Phase; ongoing \\
\hline 3 & Anatres; AREVA & France & $\begin{array}{l}\text { Prismatic fuel HTGR, } \\
625 \text { MWth per module }\end{array}$ & $\begin{array}{l}\text { Design Phase; ongoing } \\
\text { (Selected for NGNP) }\end{array}$ \\
\hline 4 & $\begin{array}{l}\text { High Temperature Reactor } \\
\text { Production Model (HTR-PM); } \\
\text { China Nuclear Energy \& } \\
\text { Construction Group (CNEC) }\end{array}$ & China & $\begin{array}{l}\text { Pebble fuel HTGR, } \\
200 \text { MWe per module }\end{array}$ & $\begin{array}{l}\text { Design Phase; start-up } \\
\text { planned for ca. } 2015\end{array}$ \\
\hline 5 & $\begin{array}{l}\text { High Temperature Test Reactor } \\
\text { (HTTR); Japan Atomic Energy } \\
\text { Agency (JAERI/JAEA) }\end{array}$ & Japan & $\begin{array}{l}\text { Prismatic fuel HTGR, } \\
30 \text { MWth }\end{array}$ & $\begin{array}{l}\text { Initial criticality in 1998; in } \\
\text { standby shutdown }\end{array}$ \\
\hline 6 & $\begin{array}{l}\text { Gas-Turbine Modular Helium } \\
\text { Reactor (GT-MHR); Rosatom, } \\
\text { OKBM, RRC (Kurchatov), } \\
\text { General Atomics }\end{array}$ & $\begin{array}{l}\text { Russia \& } \\
\text { International } \\
\text { Partners }\end{array}$ & $\begin{array}{l}\text { Prismatic fuel HTGR, } \\
287 \text { MWe per module }\end{array}$ & $\begin{array}{l}\text { Design Phase (began in } \\
\text { 1995); ongoing }\end{array}$ \\
\hline 7 & $\begin{array}{l}\text { Modular Helium Reactor, High } \\
\text { Temperature (MHR-T); Rosatom, } \\
\text { OKBM, RRC (Kurchatov), et al. }\end{array}$ & $\begin{array}{l}\text { Russia \& } \\
\text { International } \\
\text { Partners }\end{array}$ & $\begin{array}{l}\text { Prismatic fuel HTGR, } \\
600 \text { MWth per module }\end{array}$ & $\begin{array}{l}\text { Design Phase (began in } \\
\text { 2004); ongoing }\end{array}$ \\
\hline 8 & $\begin{array}{l}\text { Compact High Temperature } \\
\text { Reactor Demonstration (CHTR); } \\
\text { Bhabha Atomic Research Centre } \\
\text { (BARC), India }\end{array}$ & India & $\begin{array}{l}\text { Pebble fuel, PbBi Cooled } \\
\text { HTR, } \\
100 \mathrm{kWth}\end{array}$ & Design Phase; ongoing \\
\hline 9 & $\begin{array}{l}\text { High Temperature Reactor, } 10 \\
\text { MW (HTR-10); Tsinghua } \\
\text { University, China }\end{array}$ & China & $\begin{array}{l}\text { Pebble fuel HTGR, } \\
10 \text { MWth }\end{array}$ & $\begin{array}{l}\text { Initial criticality in } 2000 \text {; } \\
\text { operating in research mode }\end{array}$ \\
\hline 10 & $\begin{array}{l}\text { THTR-300; HTRB GmbH, KFA- } \\
\text { Juelich, Germany }\end{array}$ & Germany & $\begin{array}{l}\text { Pebble fuel HTGR, } \\
300 \text { MWe }\end{array}$ & $\begin{array}{l}\text { Initial criticality in 1983; } \\
\text { shutdown and } \\
\text { decommissioned }\end{array}$ \\
\hline 11 & $\begin{array}{l}\text { Fort St. Vrain; General Atomics } \\
\text { and PSC Colorado }\end{array}$ & USA & $\begin{array}{l}\text { Prismatic fuel HTGR, } \\
330 \mathrm{MWe}\end{array}$ & $\begin{array}{l}\text { Initial criticality ca. } 1972 \text {; } \\
\text { shutdown and converted to } \\
\text { natural gas power plant }\end{array}$ \\
\hline
\end{tabular}




\section{IAEA SAFEGUARDS}

The legal basis for implementing IAEA safeguards is the international safeguards agreement between the country and the IAEA, concluded pursuant to the Treaty on the Non-Proliferation of Nuclear Weapons (NPT). The NPT requires each Non-Nuclear-Weapon State party to the NPT to conclude a comprehensive safeguards agreement (CSA) with the IAEA, modeled on IAEA document INFCIRC/153 (corrected), The Structure and Content of Agreements between the Agency and States Required in Connection with the Treaty on the Non-Proliferation of Nuclear Weapons. ${ }^{12}$ A State may also conclude an additional protocol (AP) to its safeguards agreement, which requires the State to provide broader information and IAEA access to locations related to its nuclear fuel cycle beyond that provided by the CSA.

The objective of international (IAEA) nuclear safeguards is the timely detection of the diversion of significant quantities of nuclear material from peaceful to non-peaceful uses, and the deterrence of such by the risk of early detection. ${ }^{12}$ In addition, the IAEA must detect any potential misuse of the facility for undeclared purposes (e.g. undeclared receipt, transfer, irradiation, or removal of nuclear fuel). To summarize, the overarching IAEA safeguards objectives common to all states with a CSA and AP are to detect:

- Diversion of declared nuclear material at facilities and locations outside facilities (LOFs)

- Undeclared production or processing of nuclear material at facilities and LOFs

- Undeclared nuclear material and activities anywhere in the State.

The IAEA is currently in transition moving towards a state-level safeguards approach and will rely less on facility-centric safeguards criteria in the future. In the interim, the safeguards goals summarized below continue to define key elements of the safeguards approach, tools, and measures the IAEA may apply. Relevant safeguards goals are cited from the IAEA Safeguards Criteria for inspecting "Other Types of Reactors," found in the IAEA Safeguards Manual and associated annexes, which have been incorporated into the IAEA Quality Management System (QMS). ${ }^{13,14}$

\section{Safeguards Detection Goals}

The specific IAEA detection goals relevant to safeguarding a pebble fuel HTGR are:

- Detect the diversion of $8 \mathrm{~kg}$ of plutonium in the form of unirradiated fresh fuel within one month of possible diversion, or in the form of irradiated core or spent fuel within three months of possible diversion.

- Detect the diversion of $25 \mathrm{~kg}$ of U-235 in the form of unirradiated highly enriched fuel (HEU; U$235 \geq 20 \%$ ) within one month of possible diversion, or in the form of irradiated core or spent fuel within three months of possible diversion.

- Detect the diversion of $8 \mathrm{~kg}$ of U-233 in the form of unirradiated fuel within one month of possible diversion, or in the form of core or spent fuel within three months of possible diversion.

- Detect the diversion of $75 \mathrm{~kg}$ of U-235 in the form of depleted, natural, or low enriched uranium fuel (LEU; U-235 <20\%) within one year of possible diversion.

- Detect the diversion of 20 tonnes of thorium in the form of fuel within one year of possible diversion.

- Detect possible misuse of the facility for undeclared nuclear activities (e.g. undeclared fuel irradiation, production of plutonium or U-233, and subsequent removal of the fuel). 


\section{Traditional vs. Integrated Safeguards}

The detection goals under traditional (facility-level) nuclear safeguards are as noted above. In general, these same goals apply under integrated safeguards. The IAEA defines integrated safeguards as the "optimum combination of all safeguards measures available to the IAEA under comprehensive safeguards agreements and additional protocols to achieve maximum effectiveness and efficiency in meeting the IAEA's safeguards obligations within available resources." ${ }^{15}$ More will be said about the safeguards strategy envisioned for a pebble fuel HTGR in Section-3.

A key distinction regarding integrated safeguards is that it is applied to the country as a whole. Traditional IAEA safeguards were applied at the level of the facility. However, the objectives of detecting the diversion of significant quantities of nuclear material or misuse of the facility remain relevant, as well as the material goal quantities. If a pebble fuel HTGR were under integrated safeguards, additional measures such as the use of remotely monitored safeguards equipment, satellite imagery, and/or shortnotice random inspections (SNRI) could enable a reduction in the frequency and number of on-site inspections. This is an example of achieving maximum effectiveness, as well as efficiency.

In terms of design, the facility must accommodate IAEA safeguards equipment (e.g. seal, surveillance, and fuel flow monitoring systems), regardless of whether the pebble fuel HTGR is under traditional (facility-level) or integrated safeguards. As the pebble fuel HTGR is being designed and constructed, the facility operator, State Regulatory Authority, and IAEA should also discuss whether the reactor will need to accommodate other measures, such as the remote monitoring of safeguards equipment.

\section{Safeguards Responsibilities}

Engagement and dialog between the facility operator, designer, State Regulatory Authority, and IAEA should begin early in the design process to ensure that IAEA safeguards goals can be efficiently and effectively met. The proposed timing for the engagement of the stakeholders in the case of a model design and construction project is described in more detail in the reference noted. ${ }^{16}$

In the context of SBD, the safeguards related responsibilities can be summarized as follows:

- Facility Designer: Design the facility, per the requirements of the facility owner and operator (customer) to meet the specified operational objectives, and to be compliant with relevant national and international regulations, requirements, and guidelines. These include, but are not limited to nuclear safety, security, and safeguards regulations, requirements, and guidelines. The facility designer should design the facility in a manner that accommodates IAEA safeguards equipment and systems, facilitates design verification for safeguards purposes, and facilitates IAEA inspection activities during construction, operation, and decommissioning of the facility.

- Facility Operator: Operate the nuclear facility, for the purposes as declared to the State Regulatory Authority, in accordance with relevant national and international regulations, requirements, and guidelines. The facility operator prepares the construction specifications for the facility, which include specifications for implementing effective nuclear safeguards and providing space and utilities for nuclear safeguards equipment and measures. The facility operator hosts IAEA inspections and operates the facility in the manner declared to the IAEA.

- State Regulatory Authority: Oversee the implementation of national (domestic) nuclear regulations within the country, particularly those pertaining to nuclear safety, security, and safeguards. The State Regulatory Authority ensures effective accounting, control, and regulated use of nuclear material within the country and liaises with the IAEA to ensure the effective implementation of international nuclear safeguards as per the safeguards agreement. Dialog and engagement with the IAEA is coordinated through the State Regulatory Authority/SSAC. 
- IAEA: Verify that the country is upholding its international safeguards agreement with the IAEA, concluded pursuant to the NPT. The IAEA Department of Safeguards uses the safeguards measures available to ensure that significant quantities of nuclear material have not been diverted from peaceful to non-peaceful uses within the defined timeliness goal for detection, and uses the risk of early detection to minimize the threat of diversion.

\section{ELEMENTS OF DESIGN RELEVANT TO SAFEGUARDS}

\section{Nuclear Material Balance Areas and Key Measurement Points}

In international safeguards, nuclear material accountancy is the safeguards measure of fundamental importance with containment and surveillance (seal, surveillance, and radiation detection systems) used as important complementary measures. Simply stated, nuclear material accountancy is the accounting and control of the nuclear material inventory and related inventory changes with independent verification by the IAEA.

To account for the nuclear material inventory and associated changes, the facility operator defines a nuclear material balance area (MBA), in consultation with the IAEA. Each separate HTGR would typically be defined as a separate and distinct facility and MBA. The facility owner/operator and designer propose the MBA layout and structure to the State Regulatory Authority. To facilitate this discussion, an MBA layout diagram should be prepared by the facility designer at the earliest design stage, because it allows the stakeholders to visualize the overarching issues regarding the safeguarding of the nuclear material (i.e. where the nuclear material is stored and where the inventory and associated changes can be verified). It is advisable to involve the IAEA in these discussions at an early stage, because the layout of the MBA and associated key measurement points (KMPs) impacts the implementation of nuclear safeguards. An example of a typical MBA layout diagram for a pebble fuel HTGR is shown in the figure below. Note that this is for the simplest case of a single fresh fuel and spent fuel storage area and reactor core.

Inventory KMPs (lettered and depicted as dark blue circles) are where the nuclear material would be stored and made accessible for inventorying and verification by the facility operator, State Regulatory Authority, and IAEA. Inventory flow KMPs (numbered and depicted as light blue diamonds) are located to verify the inventory changes or transfers.

The example below shows the most basic MBA layout diagram for a typical pebble fuel HTGR, similar to the South African PBMR. Like the prismatic fuel HTGR and LWR, the nuclear fuel is stored primarily in the following inventory KMPs:

- KMP-A: Fresh Fuel Storage

- KMP-B: Reactor Core Fuel

- KMP-C: Reactor Spent Fuel Storage

The following additional KMP are also envisioned for the case of the pebble-fuel HTGR:

- KMP-D: Damaged Fuel

- KMP-E: Graphite and Used (Partially Irradiated) Fuel

- KMP-F: Post Irradiation Examination (PIE) Area 


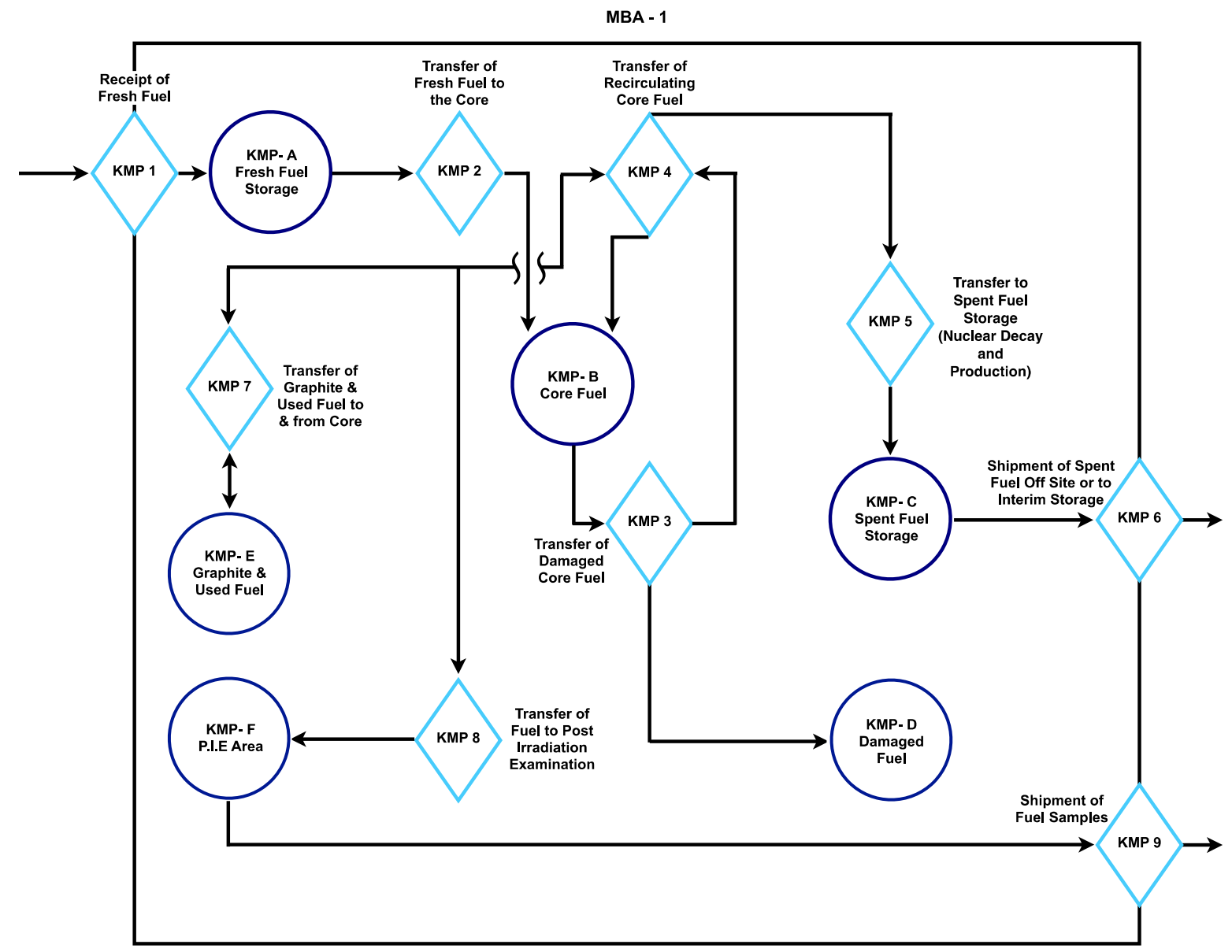

Figure-1: Typical Material Balance Area (MBA) Layout and Key Measurement Points (KMPs) for a Pebble Fuel HTGR

(Source - DNE/INL, 2010)

These additional KMPs are required in the case of the pebble fuel HTGR, because nuclear fuel will be stored in these areas. To achieve initial criticality, the pebble fuel HTGR starts up with a large loading of graphite pebble moderator in the core. As plutonium and/or U-233 accumulate in the core and augment nuclear fission, graphite moderator is drawn off the core and recirculated to the graphite pebble storage vessels. If the core needs to be defueled, partially irradiated fuel pebbles are routed to vessels dedicated for irradiated (but not spent) pebble fuel. If the pebble fuel becomes broken or damaged during recirculation, it is routed to vessels for storing irradiated damaged fuel. The discrimination and sorting of the pebble fuel would be done by the facility operator's installed radiation detectors and fuel flow monitoring system. Most pebble fuel HTGR designs at this stage also include a localized PIE area for taking and examining fuel samples, to ensure that the core pebble fuel achieves optimum burn-up. Since this is an area where small quantities of pebble fuel may be stored, it too has a defined inventory KMP. These inventory KMPs are highlighted, because they are required uniquely in the case of the pebble fuel HTGR.

If the facility is a modular design that has multiple reactor cores and/or fresh fuel and spent fuel storage areas, each would typically have a unique inventory KMP designation.

To verify the pebble fuel receipts, transfers, and shipments as outlined, the following flow KMPs would typically be required: 
- KMP-1: Fresh Fuel Receipts

- KMP-2: Fuel Transfers from Fresh Fuel Storage to the Reactor Core

- KMP-3: Irradiated Fuel Transfer from the Reactor Core to Spent Fuel Storage

- KMP-4: Transfer of Recirculating Core Fuel

- KMP-5: Transfer of Spent Fuel to Storage

- KMP-6: Spent Fuel Transfer/Shipment from the MBA/Facility

- KMP-7: Transfer of Used Fuel and Graphite Moderator to and from the Core

- KMP-8: Transfer of Fuel Specimens to the PIE Area

- KMP-9: Transfer/Shipment of Fuel Specimens from the MBA/Facility

In this discussion, it is important to note that nuclear production and "loss" (i.e. radionuclides created or consumed by nuclear reactions) would be accounted for in flow KMP-7 and KMP-5 at the time irradiated nuclear fuel is transferred from the reactor core to used and spent fuel storage. From an accounting standpoint, it is important to recognize that irradiated fuel can also be moved from used fuel storage back into the reactor core in some cases (e.g. to maximize fuel burn-up). In these cases, the accounting for the associated nuclear loss and production would be reversed, until the fuel is finally removed from the core and transferred to spent fuel storage for good.

\section{Safeguards Strategy and Possible Diversion Scenarios}

The development of the "Safeguards Approach" for a particular facility (in the official sense) is the strict purview of the IAEA. However, to implement SBD, the facility designer must anticipate where the nuclear material could be removed and diverted. This analysis should not be viewed as doing the work of the IAEA. It merely helps prepare the facility designer and operator for subsequent discussions with the IAEA on this subject. It also helps the facility designer and operator address domestic nuclear safeguards issues as well.

In this discussion, the reader should be mindful that IAEA nuclear safeguards measures and equipment evolve over time. Best practices are also continuously being improved by the IAEA and facility operator to be more efficient and cost effective. Consequently, the IAEA should be consulted regarding specific design details and issues.

The following process description is summarized from the cited reference, pertaining to the South African PBMR.${ }^{17}$ In this example, fresh fuel is delivered to the reactor and stored in shipping drums in the fresh fuel storage area. The fresh fuel pebbles are loaded into fresh fuel feed hoppers to be pneumatically conveyed to the reactor core. The core is loaded with a combination of pebble fuel and moderator to initiate criticality. After the control rods are withdrawn and nuclear criticality is reached, the pebble fuel is recirculated and excess moderator is gradually drawn off using the facility operator's fuel flow monitoring system, which can discriminate fuel from moderator. The fuel flow monitoring system actuates remotely controlled valves, which allow the irradiated moderator pebbles to be recirculated back to the moderator storage vessel.

After several years, the optimum fuel burn-up is reached and the operator's fuel flow monitoring system actuates remotely operated valves that route the spent fuel pebbles to the spent fuel storage vessels. As spent pebble fuel is transferred to storage, fresh pebble fuel is conveyed to the core.

If the fuel flow monitors detect broken or damaged pebbles, they are similarly routed to the damaged fuel storage vessel. If for some reason, the reactor core needs to be inspected, the irradiated core fuel can be pneumatically conveyed to the used or irradiated fuel storage vessel(s). 
Periodically, samples of pebble fuel are pneumatically transferred to the PIE area, where the facility operator can assess fuel burn-up and mechanical integrity. In current designs, the fuel may be kept indefinitely on location in the spent fuel storage vessels, since these are comparable to other spent fuel dry storage casks. However, the spent fuel may also be pneumatically conveyed to spent fuel transfer/storage casks for transfer or shipping to independent spent fuel storage installations (ISFSI).

Based on this example, the diversion scenarios that would need to be addressed by the safeguards strategy are:

1. Diversion of fresh pebble fuel during shipment, upon receipt, or from inventory (KMP-A)

2. Diversion of fresh pebble fuel during transfer to the reactor core (KMP-A \& B)

3. Diversion of irradiated core pebble fuel during recirculation (KMP-B)

4. Diversion of spent pebble fuel from storage (KMP-C)

5. Diversion of spent pebble fuel during shipment from storage to another location (KMP-C)

6. Diversion of irradiated pebble fuel from the damaged fuel storage vessel (KMP-D)

7. Diversion of irradiated pebble fuel from the moderator/used fuel storage (KMP-E)

8. Diversion of irradiated pebble fuel through the PIE area (KMP-F)

In this discussion one should keep in mind that the nuclear fuel is in the form of tennis ball-sized fuel pebbles containing gram quantities of nuclear material. The number of fuel pebbles that would constitute an IAEA significant quantity varies depending on the fuel composition and radionuclides present (i.e. uranium, thorium, U-233, U-235, and/or plutonium). Studies to date indicate that a significant quantity would be equivalent to 50000 to 90000 pebbles - (plutonium bearing spent pebble fuel in the former case and un-irradiated low-enriched uranium/thorium pebble fuel in the latter) ${ }^{18}$ IAEA safeguards measures are not intended to monitor individual fuel pebbles, but to detect the diversion of thousands because of the low nuclear material content per fuel pebble.

A quick sketch of the typical safeguards strategy is presented to discuss the safeguards relevant design elements or features. The safeguards strategy and approach will be discussed in more detail in the next section. The following discussion is not meant to describe exactly how the IAEA will safeguard the pebble fuel HTGR. It is merely an aid to the facility designer to help them understand the kind of safeguards measures and equipment that the facility design would need to accommodate.

To address Diversion Scenario-1, the IAEA would typically verify the fresh fuel after the fuel has been received at the pebble fuel HTGR. The particular safeguards measures employed will be discussed in more detail in Section-4. Alternatively, the fresh fuel may be verified by the IAEA at the fuel fabrication facility and the fresh fuel shipped under IAEA seal. In this case, the IAEA would verify the seals upon receipt at the pebble fuel HTGR and keep the fuel under containment and surveillance measures (i.e. seals, surveillance, and radiation detection systems).

To address Diversion Scenario-2, the IAEA would verify transfer of fresh pebble fuel to the reactor core using an independent fuel flow monitoring system in combination with seals, surveillance, and radiation detection systems. The IAEA would address Diversion Scenario-3, 4, 6, 7, and 8 similarly, i.e. fuel flow monitors would be used to verify the transfer of pebble fuel to the correct storage vessels and seals, surveillance, and radiation detection systems would be used to detect undeclared removal of pebble fuel from these areas. In principle, the fuel flow monitor would also detect the misrouting and removal of pebble fuel through other areas as well (e.g. PIE area).

To address Diversion Scenario-5, the IAEA would use fuel flow monitors and surveillance to detect undeclared removal of spent pebble fuel during pneumatic conveyance to the spent fuel transfer/storage 
casks. The IAEA would likely seal the spent fuel transfer/shipping casks, since re-verification of the spent fuel would be challenging at the ISFSI or long-term repository.

Regarding potential facility misuse, the primary misuse scenario is:

1. Undeclared use of the pebble fuel HTGR to irradiate target fuel for subsequent removal and undeclared separation of plutonium or U-233.

To address this misuse scenario, the IAEA would likely use a combination of seals, surveillance, and fuel flow monitoring systems to detect undeclared removal of pebble fuel, potentially containing target material. It may also be possible to periodically extract random samples of the core pebble fuel for analysis in the PIE area, to verify that the pebble fuel isotopic composition is as declared (i.e. the core does not contain significant nuclear target material).

To help address the foregoing diversion and misuse scenarios, the IAEA will also periodically examine and verify the safeguards relevant facility information (i.e. perform DIE/DIV) over the lifetime of the facility to ensure that the facility has being constructed and is being operated as declared.

More will be said about the particular safeguards measures in Section-4.

\section{Design Features Relevant to Safeguards}

From the foregoing discussion, the pebble fuel storage areas and the associated fuel transfer paths should be designed to accommodate the following:

- IAEA seal systems

- IAEA surveillance systems

- IAEA radiation-based fuel flow monitors

- Safe engineered access for nuclear material and design verification (by direct or indirect means)

- Possible remote monitoring and transmission of data from IAEA seal, surveillance, and radiation detection systems

- Emerging safeguards measures.

As shown in Figure-1, there are typically more inventory KMPs in a pebble fuel HTGR than in a prismatic fuel HTGR or LWR. These inventory KMPs would typically be covered by IAEA seal and surveillance systems, with IAEA fuel flow monitors covering the fuel transfer pathways in between. As a consequence, the hatches, doors, and access ports to the areas where pebble fuel is stored would need to accommodate IAEA seals. Provisions must also be made for the placement of IAEA surveillance systems to cover access to the pebble fuel storage and handling areas.

Access to the following would likely be sealed by the IAEA and placed under surveillance:

- Fresh pebble fuel storage drums and feed hoppers

- Reactor vessel service hatch(es)

- Spent pebble fuel storage area

- Damaged pebble fuel storage area

- Graphite moderator and used (irradiated) fuel storage area

- PIE hot cell

- Reactor building equipment hatch(es). 
Additionally, the IAEA surveillance cameras, radiation detectors, and associated data collection cabinets would also be sealed.

The requirements for the common IAEA sealing systems are noted in Section-5. Surveillance systems would typically be used, in addition to the seal systems, to detect undeclared removal of pebble fuel, especially from the pebble fuel storage areas and reactor core. The arrangement and location of the IAEA surveillance systems would need to be discussed in advance between the facility operator, designer, State Regulatory Authority, and the IAEA. This would ensure that when the IAEA surveillance systems are installed they will have the requisite space and utilities. In locating the surveillance cameras, the IAEA will design the systems to have overlapping coverage. The space and utility requirements for the most common IAEA surveillance systems are noted in Section-5. Because of the on-load refueling of the pebble fuel HTGR, the IAEA would likely use radiation-based fuel flow monitors to verify the declared pebble fuel transfers. The same concerns regarding the placement and installation of the surveillance cameras applies to the installation of the radiation detectors and fuel flow monitors as well. The most common radiation detectors and fuel flow monitors and the associated requirements are noted in Section5.

Keeping these points in mind, it is important that the designer provide space and utilities to accommodate the foregoing safeguards equipment. The facility design should not be so densely packed with equipment to preclude effective surveillance and monitoring of the nuclear fuel inventory locations and fuel transfer paths. Similarly, surveillance and monitoring of the pebble fuel transfer cask entry and exit locations should not be obstructed.

Because the pebble fuel transfer paths are numerous and would not normally be visible, the IAEA is likely to place even greater emphasis on the use of DIE/DIV to verify that the fuel storage vessels and transfer paths have not been altered or enhanced. Consequently, the IAEA will need a pre-installed capability to confirm that the volume of the pebble fuel storage and reactor vessels remains as declared, and that fuel pneumatic transfer paths have not been added or altered. This will be discussed in more detail in Section-4.

See the Appendix regarding emerging technologies relevant to safeguarding future pebble fuel HTGR. Although these safeguards measures are still being demonstrated and optimized, the IAEA may decide to use some or all of these measures to safeguard pebble fuel HTGR more efficiently in the future as this reactor type is more widely deployed.

\section{KEY ELEMENTS OF SAFEGUARDS STRATEGY/APPROACH}

The safeguards strategy envisioned for a pebble fuel HTGR has been outlined, but is described in this section in more detail. The strategy focuses on accounting for the receipts, inventory, and shipments of pebble fuel, to detect nuclear material diversion and facility misuse (i.e. removal of undeclared target fuel). Seal, surveillance, and fuel flow monitor systems are used to maintain continuity of knowledge of the fuel in the reactor core and pebble fuel storage areas. Because re-verification of irradiated fuel in the reactor core and in spent fuel storage may be disruptive, the IAEA uses redundant containment and surveillance measures that do not share a common mode of failure. To date, the IAEA has relied heavily on seal and surveillance systems, because these are easy to install, service, and evaluate. Because of the on-load refueling of the reactor and continuous recirculation of the pebble fuel, the IAEA will also likely use radiation-based fuel flow monitors. If the pebble fuel HTGR has multiple reactor cores and fresh and spent fuel storage areas, the IAEA would install multiple containment and surveillance systems with overlapping coverage.

\section{Nuclear Material Accountancy}

The IAEA examines the facility operating/accounting records, source documents, and reports submitted by the State Regulatory Authority for consistency, regarding the pebble fuel inventory and changes in the reactor core(s) and pebble fuel storage areas. The inspector verifies that the pebble fuel 
receipts, inventory, and shipments are as declared by the facility operator. The inspector also examines the facility instrument records for the declared period of operation and irradiation of the core, to verify that the period of operation is consistent and as declared. Because the reactor is continuously refueled while in operation, the inspector will likely compare data from the IAEA fuel flow monitor for consistency against the facility operator's declarations for the pebble fuel flows to and from the reactor core. This activity typically takes place in an available office at the pebble fuel HTGR. Associated field inspection activities are described below.

\section{Verification of Fresh Pebble Fuel Receipts and Inventory}

If the fresh pebble fuel is verified at the fuel fabrication facility, it may be shipped under IAEA seal to the pebble fuel HTGR. At the HTGR, the IAEA inspector verifies the seals, checks for tampering, and observes the storage of the sealed fuel casks. The number and ID of the fresh fuel casks and final storage locations are confirmed by the inspector to be as declared by the facility operator. Alternatively, the fresh pebble fuel may not be sealed during transit. In this case, the nuclear material content of the fuel (i.e. uranium, thorium, plutonium, U-235, and U-233) is verified at the pebble fuel HTGR by the IAEA inspector using NDA instruments. The particular instruments currently used by the IAEA for this purpose, and the associated space and utility requirements, are described in Section-5. In addition to verifying the nuclear material content, the inspector will likely verify the mass of the pebble fuel casks using an IAEA Load Cell Balance System (LCBS) or the facility operator's scale, which has been calibrated and verified by the inspector. Regarding the frequency of verification, if the pebble fuel contains LEU (U-235 <20\%) or thorium, the IAEA typically verifies the fresh fuel once per year at the time of the physical inventory verification (PIV). If however, the fresh pebble fuel contains direct-use material (i.e., plutonium, HEU, or U-233), then the IAEA verifies the fresh fuel every one to three months, because of the more stringent timeliness goal for detecting a diversion. After the fresh fuel has been verified by the IAEA and placed in storage, containment and surveillance measures (seal, surveillance, and fuel flow monitoring systems) are used to detect the undeclared movement or removal of fresh pebble fuel, especially if it contains direct-use material.

If the fresh fuel casks are sealed, the facility operator may detach the IAEA seal, provided that advanced notice regarding the seal detachment and fuel movement has been given to the IAEA (e.g. transferring stored fresh pebble fuel to the fresh fuel feed hopper).

\section{Verification of Pebble Fuel in the Core and Associated Transfers}

Seal, surveillance, and fuel flow monitoring systems are used to detect and verify the transfers of pebble fuel to and from the core. Typically, the IAEA would seal hatches, covers, or ports that access the reactor core. Seals are periodically replaced by the inspector to detect potential tampering. Video surveillance systems are reviewed to detect undeclared removal of pebble fuel. The reactor core itself is considered "difficult to access." Consequently, it is envisioned that fuel flow monitors would be used to verify the pebble fuel transfers to and from the core and the associated pebble storage vessels (i.e. graphite moderator, damaged, used, and spent pebble fuel.) The same fuel flow monitor would be used to detect pebble fuel transfers from the core to the PIE hot cell. Typical IAEA fuel flow monitoring systems, gamma and neutron detectors, and the associated space and utility requirements are described in Section5. Historically, the IAEA has installed fully independent fuel flow monitoring systems and radiation detectors. However, in principle, it is possible for the facility operator and IAEA to share the fuel flow monitoring system, provided the IAEA can independently verify the safeguards data collected by the system. In addition to verifying the pebble fuel transfers to and from the reactor core, the IAEA would periodically verify the pebble fuel in the reactor core itself. In principle, successful operation of the seal, surveillance, and fuel flow monitoring systems may permit the IAEA to indirectly verify the pebble fuel in the reactor core by deduction. However, the facility designer should consider the need to re-verify the pebble fuel HTGR core in the event that the seal, surveillance, and/or fuel flow monitoring systems fail. With this in mind, a means to re-verify the pebble fuel and volume of fuel in the reactor core should be 
provided. This could be in the form of an installed instrument well adjacent to the reactor vessel for IAEA gamma and neutron detection probes, which could verify the gross attributes of the partly irradiated pebble fuel in the core, as well as the fuel fill-height or volume in the core.

Additionally, the IAEA examines the facility operating and accounting records pertaining to irradiation of the core and compares with installed instruments to verify that there were no undeclared reactor shutdowns or outages. The IAEA also verifies the declared nuclear material content of the spent fuel, using a suitable fuel burn-up code (e.g. ORIGEN) based on the fuel irradiation history.

\section{Verification of Spent Pebble Fuel Inventory and Shipments}

Fuel flow monitoring systems are likely to be used to verify and count spent pebble fuel transferred from the core to storage and the inventory of spent pebble fuel in storage. Seal and surveillance systems are used to detect the removal of irradiated and spent pebble fuel from the storage area and shipments of spent fuel transfer casks from the facility. If spent pebble fuel is shipped from the facility, the shipment may be verified by the IAEA at the receiving location. Alternatively, the spent pebble fuel shipping cask(s) and contents may be verified by the IAEA using NDA at the pebble fuel HTGR, and the casks sealed by the IAEA prior to shipping off site. If the shipment is sealed by the IAEA at the pebble fuel HTGR, the seals are verified and randomly replaced by the inspector at the receiving location to detect potential tampering of the spent pebble fuel during transit. Video surveillance systems at the pebble fuel HTGR are reviewed to verify that the shipments of spent pebble fuel transfer casks are as declared by the facility operator. Based on IAEA experience at MOX fueled LMFBR, it would be possible to use radiation-based fuel flow monitors, in combination with seal and surveillance systems, to provide assurance that there have been no undeclared removals of irradiated and spent pebble fuel from the reactor vessel and irradiated pebble fuel storage vessels. If the seal, surveillance, and fuel flow monitoring systems covering the spent HTGR fuel storage fail, or indicate potential tampering, the spent pebble fuel would need to be re-verified. How this could be done should be discussed between the facility operator, designer, State Regulatory Authority, and the IAEA. This is discussed in more detail in the Appendix, regarding emerging technologies and safeguards measures.

\section{Detection of Potential Facility Misuse (Including Undeclared Activities)}

The primary misuse scenario involving a pebble fuel HTGR would be the undeclared irradiation of specially designed pebble target fuel, removal of the irradiated fuel, and subsequent separation of the plutonium or U-233. The IAEA uses seal, surveillance, and fuel flow monitoring systems to detect undeclared removals of pebble fuel, including undeclared irradiated target fuel. The IAEA also examines the declared operating and accounting records against the facility's instruments to verify that no undeclared shutdowns or outages occurred, which might permit the undeclared removal of irradiated bulk target fuel. Since the pebble fuel HTGR is an on-load refueled reactor, use of the fuel flow monitor would be key to detecting the insertion and removal of specially designed pebble target fuel. The IAEA would also likely use seals and surveillance on the PIE hot cell to verify that the PIE transfer route is not misused for the undeclared transfer and removal of pebble target fuel, or the PIE hot cell misused for undeclared lab-scale separation of plutonium or U-233.

\section{Detection of Nuclear Material Borrowing}

"Nuclear material borrowing" is the undeclared borrowing or exchange of similar nuclear material between facilities in the country in an effort to misrepresent the available nuclear material inventory and deceive the IAEA. The IAEA uses seal, surveillance, and fuel flow monitoring systems to detect the undeclared removal or "borrowing" of fresh, core, and spent pebble fuel. They would also conduct inspections at the pebble fuel HTGR simultaneously with other facilities in the country that could share or swap fuel, such as the pebble fuel fabrication plant and ISFSIs where spent pebble fuel may be stored. 


\section{Verification of Facility Design Information}

Over the life of a nuclear facility, the IAEA examines and verifies the facility design information relevant to nuclear safeguards. This activity is called design information examination and verification or DIE/DIV. The inspector uses information provided by the facility operator and designer in the IAEA Design Information Questionnaire (DIQ), which typically includes the following drawings and design information:

- Facility MBA diagram(s), showing the pebble fuel inventory and flow KMPs and fuel transfer paths

- Process description that states how the fuel would be received, stored, transferred, irradiated, and shipped from the pebble fuel HTGR

- Design of the fresh pebble fuel storage vessels and area

- Design of the pebble fuel feed and pneumatic transfer/recirculation system

- Design of the irradiated pebble fuel storage vessels and area (including vessels for storing used (partly irradiated), damaged, and spent pebble fuel, and graphite moderator)

- Design of the pebble fuel HTGR reactor vessel(s)

- Design of the fresh pebble fuel shipping cask, including cask capacity and estimated frequency of receipts

- Design of the spent pebble fuel shipping cask, including cask capacity and estimated frequency of shipments

- Design of the facility operator's fuel flow monitoring system

- Fuel burn-up code that shows how the radionuclide content of the spent pebble fuel would be calculated

- Equipment layout of the pebble fuel HTGR, showing the dimensions and locations of the reactor vessel, fresh and irradiated/spent pebble fuel storage areas, and pebble fuel pneumatic transfer paths

- Other drawings and information deemed necessary by the IAEA for safeguarding the facility.

The IAEA performs DIE/DIV at the facility to ensure that it has been designed and constructed as declared, i.e. that there are no concealed locations for the storage, transfer, or irradiation of pebble fuel. The inspector typically uses hand tools, instruments, and the DIQ to verify the design information. If the facility is of a new design (such as the pebble fuel HTGR) the IAEA may use the 3D Laser Range Finder (3DLR). This is a modified laser-based survey instrument that allows the inspector to measure and confirm the construction and dimensions of large and complex facilities. More will be said about this instrument in Section-5. The safeguards inspector performs DIE/DIV at the facility as it is being built and periodically during operation, until it is officially shutdown and decommissioned (from the standpoint of safeguards).

\section{SAFEGUARDS BEST PRACTICES RELEVANT TO THE DESIGN}

There are a number of safeguards related considerations that the designer of a pebble fuel HTGR should take into account when designing the facility. The following reflects the current safeguards measures, which are continuously evolving. The facility designer and operator should discuss these issues in detail with the State Regulatory Authority and the IAEA during the design of the HTGR to confirm the measures to be used and evolving trends. 


\section{Layout Requirements}

A layout schematic for the safeguards equipment at a pebble fuel HTGR is shown in the figure below. This figure is intended merely as an example for illustration. The reader should note that this example shows a single reactor core and fresh and spent fuel storage area. Because many of the current pebble fuel HTGR designs are modular, additional reactor cores and fresh and spent fuel storage areas could be incorporated to produce an HTGR design with a higher power output. If this were the case, the safeguards measures shown for the example would be replicated for the additional areas where pebble fuel would be located. One must also note that the actual IAEA safeguards equipment and associated layout would be determined by the IAEA, in consultation with the facility operator and State Regulatory Authority. For the reactor core and irradiated pebble fuel storage vessels, the seal and surveillance systems may be directed at the accesses hatches to those areas, rather than the vessels themselves, since they are in high radiation areas. The seals and surveillance for the PIE area may be directed at the PIE hot cell where the pebble fuel can be accessed, or the room as a whole.

If a video surveillance or fuel flow monitoring system is used that requires a data collection cabinet, the cabinet should be installed in an area or room that is protected from extreme temperature, humidity, and dust. The space and utilities required for each system are discussed further below. More detailed specifications regarding the safeguards equipment layout can be provided by the IAEA.

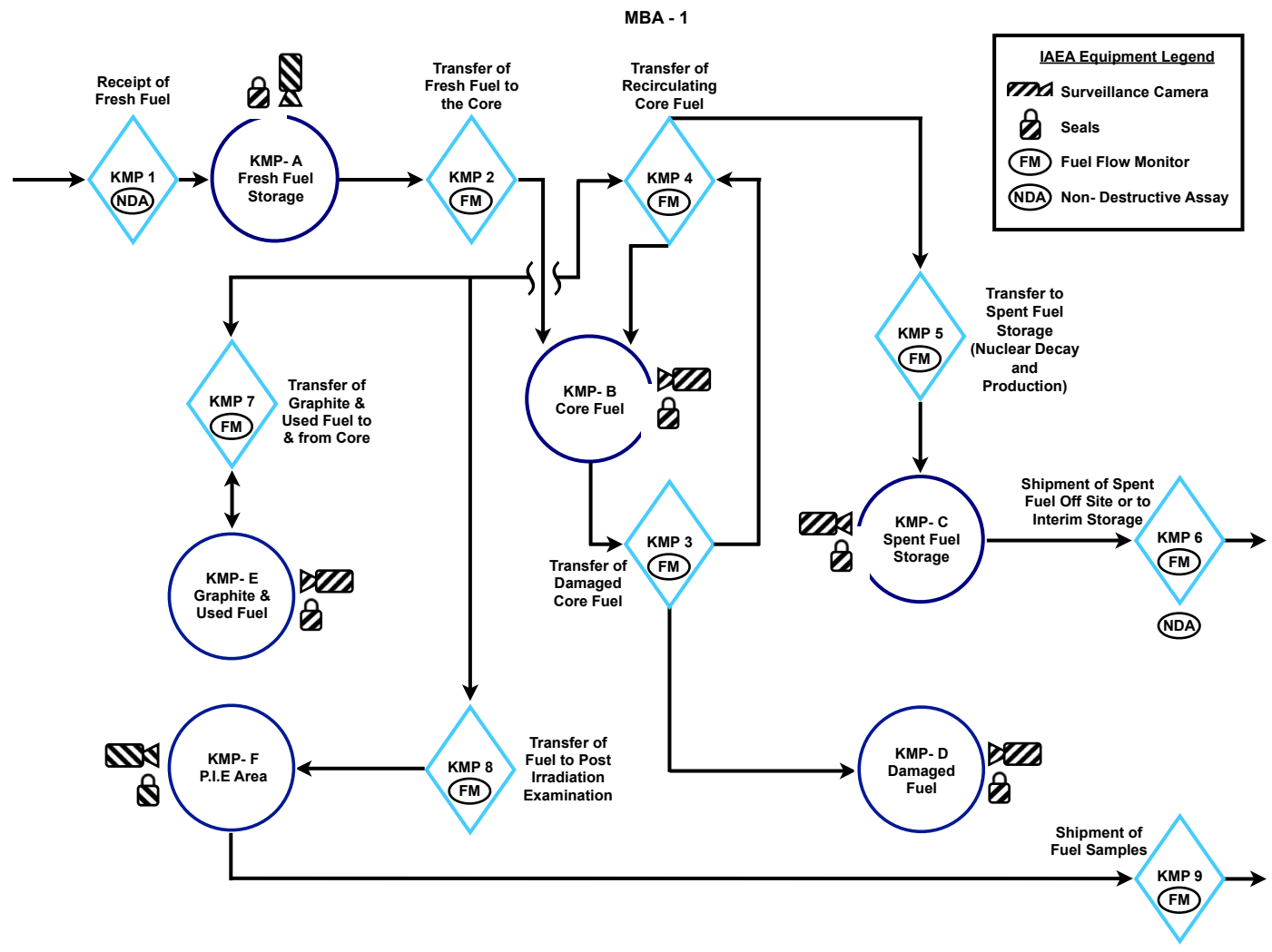

Figure-2: Typical Layout of IAEA Safeguards Equipment for a Pebble Fuel HTGR

(Source - Durst Nuclear Engineering and Consulting Inc., 2011)

Regarding the equipment layout, it is important for the facility designer to recognize that the aforementioned equipment is for IAEA safeguards. The facility operator will require separate systems for security and physical protection, such as their own dedicated surveillance camera system, motion sensors, etc. The facility operator's systems are not addressed by this safeguards guidance document, although the final HTGR layout design will need to accommodate both. 
The space and layout requirements for typical IAEA safeguards equipment are summarized below. IAEA seals are used to secure access to the reactor core, pebble fuel storage vessels, and the PIE area. How the core access is sealed depends on whether the cover consists of integral sections or individual hatch covers. If the core has individual hatch covers, it may be possible to daisy-chain and route the sealing cable through the various covers. New containment measures are discussed that could address this situation more effectively in the Appendix. One-half square meter should be allowed for servicing each seal. The seals are attached in a manner that would indicate tampering if the reactor core or irradiated pebble storage vessel areas are accessed. IAEA seals may also be applied to the fresh pebble fuel storage drums and the pebble feed hopper(s) in the fresh fuel handling area. Similarly, $0.5 \mathrm{~m}^{2}$ should be provided for attaching, replacing, or servicing the seals in these locations as well.

Surveillance cameras and systems are typically used to verify that undeclared removals of fuel from the reactor core and pebble fuel storage areas do not occur. If the fresh pebble fuel contains direct-use material (i.e., plutonium, HEU, or U-233), then surveillance cameras would likely be used to cover the fresh fuel storage area as well. Surveillance cameras are installed in a manner that provides redundant and overlapping coverage. Surveillance cameras require $1 \mathrm{~m}^{2}$ of space per camera and a clear field of view of the safeguarded area of interest. If radiation detectors are used, they also require $1 \mathrm{~m}^{2}$ of space per detector. Safe engineered and shielded access must be provided to permit servicing the seal, surveillance, and radiation detection systems. If multiple cameras or a radiation-based fuel flow monitoring system are utilized, a data collection cabinet may be used. Data collection cabinets require $3 \mathrm{~m}^{2}$ per cabinet, with safe engineered and shielded access to the front and back doors of the cabinet.

Because the pebble fuel HTGR is a continuous on-load refueled reactor with recirculating fuel, fuel flow monitors will likely be used by the IAEA to verify the fuel transfers to and from the associated pebble fuel storage vessels and reactor vessel(s). A typical IAEA fuel flow monitor and associated radiation detectors are described in more detail below. The space and layout requirements for the fuel flow monitor data collection cabinet(s) and associated gamma/neutron detectors are as noted above.

\section{Office Space}

The IAEA requires use of an office or meeting room at the HTGR for examining facility operating and accounting records, source documents and associated state reports. This room need not be dedicated office space, but may be made temporarily available on the occasion of the inspection. The review of these documents is infrequent and is performed at the time of field inspections by the IAEA inspector. This office space should have convenience electrical power outlets for the inspector's laptop computer and peripheral equipment and be $16 \mathrm{~m}^{2}$ or greater.

\section{Seal Systems}

The IAEA typically uses seals as tamper indicators on the access hatches or doors to the reactor core, and pebble fuel storage vessel and PIE areas. They may also apply seals to the fresh pebble fuel casks and feed hoppers, especially if the pebble fuel contains direct-use material. The IAEA also applies seals to the surveillance camera and radiation detector tamper-proof housings and data collection cabinets. In certain cases, two different types of seal systems may be used in case one system fails. Ideally, the two seal systems should not have a common failure mode. The seals most commonly used presently are the metal cap seal and the variable-coded sealing system (VACOS), shown in the top row of the figure below. ${ }^{19}$ Shown in the bottom row is the next generation electro-optical sealing system (EOSS), which is being field tested and will likely become the IAEA's standard seal system within the next 5 years. ${ }^{20,21}$ 

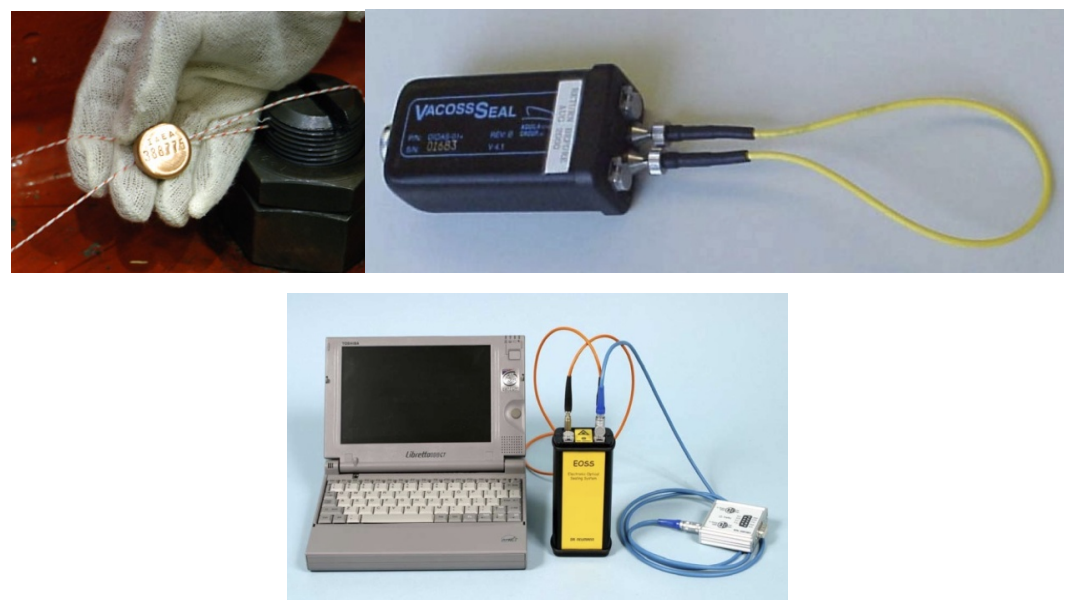

Figure-3: IAEA Seal Systems

(Source - IAEA, 2007)

To use these seals, the locking hasp and fasteners on the access doors and hatch covers to the reactor core and pebble fuel storage areas must typically be modified for routing the sealing cable. Specifications for the size of the hole drilled for the seal cable and other particulars can be provided by the IAEA. The hasps and fittings are reattached in a manner that prevents removal from outside the door or hatch cover. Similarly, the lid hardware on the fresh pebble fuel shipping casks and feed hoppers would need to be modified to permit the use of IAEA seals. In the past, facility operators have also designed metal covers and sleeves to protect IAEA seals and cables, to minimize the risk of accidentally damaging the seal during routine operation of the facility. The IAEA performs a site inspection and vulnerability assessment of the facility operator's hardware to confirm that it can be effectively sealed, without permitting undeclared removal of the nuclear material secured by the seal.

\section{Surveillance Systems}

In safeguarding a nuclear power plant, the IAEA typically uses video surveillance systems to detect fuel removal from the reactor core, spent fuel storage, and fresh fuel storage areas - (especially if the fresh fuel contains direct-use material). In the case of the pebble fuel HTGR, the IAEA will also likely use cameras to detect fuel removal from the other pebble fuel storage areas (i.e. used fuel and damaged fuel) and PIE area as well. The cameras must have a clear field of view of the accesses to the reactor vessel and pebble fuel storage areas. In the case of the pebble fuel HTGR, radiation-based fuel flow monitors are likely to be used as well, to verify the pebble fuel transfers to and from the reactor vessel. If the pebble fuel HTGR has multiple reactor modules and fresh and spent fuel storage areas, each of these will be covered by surveillance with overlapping and redundant coverage. Camera placement is determined by the IAEA, in consultation with the facility operator and the State Regulatory Authority.

The IAEA currently fields a variety of surveillance systems. However, in the near future the next generation surveillance system (NGSS) will become the IAEA standard. ${ }^{22}$ The NGSS and associated camera (in a tamper proof enclosure) are shown in the figure below.

If a multiple camera system is used, a data collection cabinet will likely be required as shown. This cabinet contains a computer server for storing the digital surveillance data and associated computer peripherals. Consequently, it should be located in a room or area that is not subject to extreme temperatures, humidity, or dust. The designer should note that the facility operator's surveillance system for security and physical protection is separate and distinct from the IAEA safeguards surveillance system. Each IAEA camera unit requires approximately $1 \mathrm{~m}^{2}$ of space with a clear field of view covering the safeguards area of interest. The data collection cabinet requires $3 \mathrm{~m}^{2}$ per cabinet and clear access to the front and rear cabinet doors. More detailed specifications for the particular surveillance system to be used can be provided by the IAEA. 


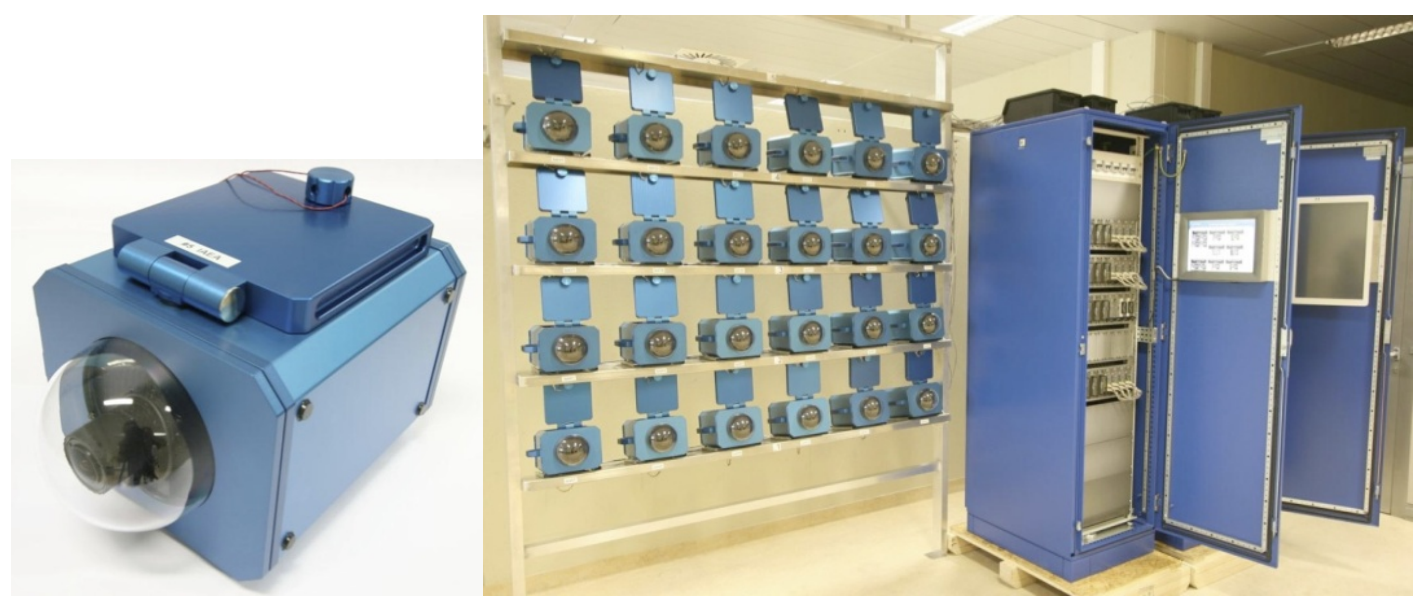

Figure-4: IAEA Next Generation Surveillance Camera and System (NGSS)

(Source - IAEA, 2010)

IAEA surveillance systems are typically installed on a facility emergency power circuit, and also connected to an IAEA un-interruptible power system (UPS), to minimize the possibility of losing surveillance due to localized power outages. The cabling used for the IAEA seal, surveillance, and fuel flow monitoring systems must be tamper resistant and is typically provided by the IAEA, especially the cabling that interconnects the cameras, seals, and radiation detectors to the data collection cabinet(s). More detailed specifications regarding the tamper resistant cabling can be provided by the IAEA.

\section{Radiation-Based Fuel Flow Monitors}

Because the pebble fuel HTGR is an on-load refueled nuclear reactor with numerous fuel flow paths, the IAEA will likely use a radiation-based fuel flow monitor to verify the transfers of pebble fuel to and from the reactor vessel(s). The fuel flow monitor could also potentially detect the undeclared removal of fuel from the various fuel storage vessels, and may permit indirect verification of the fuel inventory in the core and in the pebble fuel storage vessels. The types of radiation detection probes used will depend on the type of fuel being verified (i.e. whether it contains plutonium, HEU, thorium, or U-233). For safeguarding MOX-fueled liquid metal fast breeder reactors, the IAEA has used neutron and gamma detectors. The fuel flow monitor must be able to count, verify, and discriminate spent pebble fuel from fresh, irradiated, and damaged pebble fuel, and graphite pebble moderator. An example of a fuel flow monitoring system in tamper proof enclosures is shown in the figure below. The example consists of three data collection cabinets installed side by side. The space requirements for each cabinet are identical to those noted for the surveillance data collection cabinet. A variety of radiation detectors for gamma and neutron detection are shown in the upper right of the figure, with the longest being approximately $40 \mathrm{~cm}$. The bottom of the figure shows a rack-mounted radiation detector data collection module (NGAM) currently being evaluated by the IAEA.

The IAEA is in the process of upgrading its fuel flow monitors to a standardized configuration; although the upgraded fuel flow monitor will still fit into the current tamper proof cabinets shown. Since the newer systems are also computer-based, their utility requirements will be comparable to the example shown, which is described in more detail below. More detailed specifications regarding the particular fuel flow monitor to be used can be provided by the IAEA.

In principle, it is possible for the IAEA and the facility operator to share a fuel flow monitoring system. However, the IAEA would need to independently verify the safeguards data collected by the system. This could potentially be done by installing independent radiation detectors and/or data collection modules and computer. The degree of instrument separation and independence would need to be discussed and confirmed with the IAEA. 

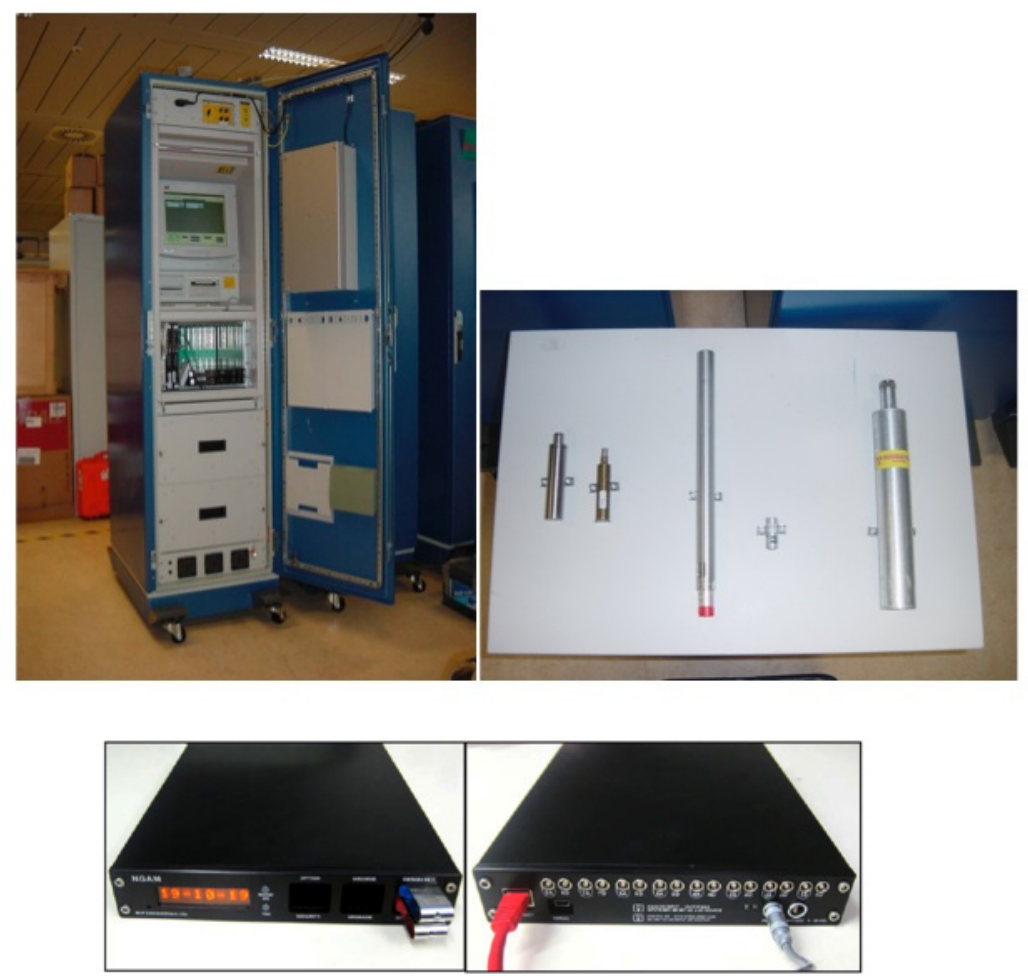

Figure-5: Radiation-Based Fuel Flow Monitoring System and Components

(Source - IAEA, $2002 \& 2010$ )

\section{Remote Monitoring}

To make more efficient use of field inspectors, the IAEA may propose remote transmission of the safeguards seal, surveillance, and fuel flow monitoring data to a nearby IAEA regional office or to IAEA HQ in Vienna, Austria. Under such an inspection regime, the IAEA would continue to inspect the facility, but at a reduced frequency, because most of the safeguards data would be continuously transmitted to the IAEA. Remote monitoring requires modification to the safeguards equipment, additional cabling and connections, and a suitable port for data transmission. The potential use of remote monitoring by the IAEA should be discussed between the facility operator, State Regulatory Authority, and IAEA early in the design of the pebble fuel HTGR, and is subject to the approval of all three stakeholders. The actual mode for the remote data transmission is rapidly evolving and has varied greatly in just the last few years. More detailed specifications regarding the remote monitoring scheme and equipment can be provided by the IAEA.

\section{Equipment for Verifying Fresh Fuel}

The NDA techniques used by the IAEA for verifying fresh (unirradiated) pebble fuel casks will likely be the same as those currently used for verifying fresh nuclear fuel containing LEU and MOX (i.e. gamma spectroscopy and passive and active coincident neutron counting). The selection and optimization of this equipment will be dictated by the pebble fuel size, geometry, and radionuclide content (i.e. U-235, U-233, plutonium, and thorium content). Examples of the equipment that the IAEA currently uses to verify fresh LEU fuel and MOX materials are shown in the reference noted. ${ }^{19}$ The main issue for the designer is providing the space and utilities for using this equipment. Two square meters of space is adequate for using most of these systems and they can all be powered using a local convenience electrical power outlet. It is important to recognize that the IAEA currently inspects very few pebble fuel HTGR. As these facilities become more common, the IAEA will likely standardize an NDA verification system 
for the new pebble fuel. In addition to verifying the nuclear material content of the fresh pebble fuel casks, the IAEA will also likely verify the gross and net weight of the pebble fuel casks, using a weighing system such as the IAEA LCBS. Alternatively, the IAEA may also use the facility operator's load cells or weighing system, provided it has been calibrated and checked by the IAEA. More detailed specifications regarding the particular equipment the IAEA will use for verifying pebble fuel can be provided by the IAEA.

\section{Equipment for Verifying Spent Fuel}

Used (partially irradiated) and spent fuel in a pebble fuel HTGR will likely be considered by the IAEA to be "difficult to access," because current designs show the reactor vessel and the used, damaged, and spent pebble fuel storage vessels located in high radiation areas. If fuel flow monitors are used, they can verify the spent fuel pebbles, as well as the fuel pebble transfers (i.e. roughly verify the nuclear material content as well as count the fuel). Historically, MOX fuel flow monitors have been able to discriminate spent fuel from partially irradiated and fresh MOX fuel, as well as dummy fuel assemblies. It is presumed that the pebble fuel flow monitor will have the same capability (i.e. to distinguish spent fuel from damaged, irradiated, and fresh pebble fuel, and graphite pebble moderator). This would consequently satisfy the IAEA requirement to verify the spent fuel to detect gross defects, i.e. detect the substitution of damaged, irradiated, or spent fuel with a non-fuel object (such as graphite pebble moderator). This equipment has been described above in the sub-section on Radiation-based Fuel Flow Monitors.

If the seal, surveillance, and fuel flow monitor systems collectively fail, the IAEA would typically reverify the used and spent fuel in storage. A means of doing this for the pebble fuel HTGR has not yet been developed and approved by the IAEA for routine use. If instrument interrogation wells are installed adjacent to the reactor and moderator, damaged, used, and spent pebble fuel storage vessels, the IAEA would have the capability to insert gamma and neutron probes and re-verify the spent fuel and fuel fillheight (volume) in storage. However, it is presumed that the fuel flow monitor will be the primary means for verifying the spent fuel as it is transferred to storage.

In the event of spent pebble fuel shipments off-site, it may be possible to verify the spent fuel shipping cask using the Compton Dry-Cask Imaging System being developed for verifying spent LWR fuel in dry storage. ${ }^{23}$ This is discussed in more detail in the Appendix, regarding emerging technologies and safeguards measures. More detailed specifications regarding the particular method and equipment for verifying spent pebble fuel can be provided by the IAEA.

\section{Design Impacts of Facilitating Inspection}

\section{i. DIE/DIV Activities}

IAEA safeguards inspectors perform DIE/DIV while the nuclear facility is under construction and after the facility begins operation, until the facility is decommissioned (from the standpoint of safeguards). In general, they verify that the facility has been designed and constructed and is being operated as declared by the facility operator in the Design Information Questionnaire (DIQ). In the case of a pebble fuel HTGR, the IAEA would verify that the HTGR does not have concealed sub-basements, chambers, storage areas, or transfer passageways for the undeclared receiving, transfer, irradiation, storage, or shipping of pebble fuel. Because of the numerous pebble fuel storage vessels and pneumatic fuel transfer paths, these will likely be examined during the DIE/DIV. The IAEA also typically verifies that the design and capacity of the HTGR reactor core and fresh and spent pebble fuel storage areas are as declared by the facility operator in the DIQ. The IAEA will further verify the design and capacity of the HTGR fuel receiving and shipping areas and fresh and spent pebble fuel transfer casks. Particular attention is paid to the fuel entry and removal routes, to confirm that the planned containment and surveillance measures would be effective in detecting the undeclared removal of pebble fuel. 
The IAEA also verifies the facility does not have undeclared shielded laboratory space, glove-boxes, and other facilities, which could be used for the clandestine reprocessing of pebble fuel. Current pebble fuel HTGR designs include a PIE area for evaluating the mechanical and physical properties of pebble fuel specimens during reactor operation. It is likely the IAEA will evaluate the capability of this laboratory during DIE/DIV for the potential undeclared separation of plutonium and/or U-233.

The space requirements for conducting the DIE/DIV are comparable to those required for performing normal facility operations or other IAEA safeguards inspection activities, i.e. adequate shielded space to walk around and inspect the fresh fuel storage area and accesses to the reactor vessel and irradiated/spent pebble fuel storage areas to ensure that the containment and surveillance measures remain effective. The IAEA inspectors also check the field of view of the surveillance cameras and radiation detectors and verify the vulnerability of the sealing systems - including the facility operator's hardware (i.e. sealing latches, hasps, nuts and bolts, doors, hatches, etc.).

The facility designer and operator should clarify how the IAEA intends to verify the design of the facility, since the density of the equipment installation and layout may preclude the use of certain IAEA equipment. However, it is important to keep in mind that the IAEA focus is not on the entire facility, but on the safeguards relevant features of the facility, with a focus on the nuclear material inventory and flow KMPs. IAEA inspectors typically use the design information and drawings provided by the operator in the DIQ, portable tools, and instruments to verify the safeguards relevant features of the design. In facilities of new design (such as the pebble fuel HTGR), the IAEA may use the 3DLR, which is described in more detail in the reference noted. ${ }^{24}$ The 3DLR is a laser-based survey instrument that requires a free line-of-sight, i.e. if the equipment layout is too dense, it may not be possible to use the instrument. Since pebble fuel HTGRs have multiple operating floors, the IAEA would typically survey all of the areas and levels were nuclear fuel could be stored or transferred, including the access hatches to the reactor vessel, pebble fuel storage vessels, and pneumatic transfer piping. The pebble fuel feed system and fresh and spent fuel transfer casks are also likely to be surveyed.

The 3DLR requires $4 \mathrm{~m}^{2}$ at each survey location and a 1 meter-wide path for moving the instrument. Clear labeling or stenciling of the access hatches to the reactor vessel, pebble fuel storage areas, and pneumatic transfer piping facilitates use of the 3DLR. Fiducials (i.e. markings) applied to walls, vessels, and piping, such as used for photogrametry, also make merging of the images collected by the 3DLR easier. The instrument can be operated from a convenience electrical outlet or on-board batteries. More detailed specifications regarding the DIE/DIV instruments to be used can be provided by the IAEA.

\section{ii. IAEA Inspections during Facility Operation}

The aforementioned IAEA safeguards inspection activities performed at a typical pebble fuel HTGR, and the requisite safeguards equipment, is now discussed from the standpoint of potential impact to the facility design. During an inspection on the site, the IAEA inspector examines the facility operating and accounting records, source documents, and state reports for consistency against the fuel inventory and inventory changes at the pebble fuel HTGR declared by the facility operator. Typically, the inspectors verify the fresh pebble fuel in the shipping casks, drums, and feed hoppers several times per year, using NDA instruments and the LCBS. The frequency of the verification depends on whether the fuel contains direct-use nuclear material (i.e. plutonium, HEU, or U-233) and the IAEA state-level approach.

To verify the pebble fuel in the reactor core, the IAEA will likely use radiation-based fuel flow monitors to count, verify, and discriminate the fuel transfers to and from the reactor core. Used together with the seal and surveillance systems, this provides continuity of knowledge of the fresh fuel, reactor core, damaged fuel, used (partly irradiated) fuel, and spent fuel KMPs, and allows indirect verification of the fuel in these KMPs.

In addition to verifying the pebble fuel inventories, the inspectors verify the fuel receipts, transfers, and shipments. The timing and frequency of the verification depends on whether the fuel contains direct- 
use nuclear material. Fresh pebble fuel receipts may be verified at the time of the receipt or during a scheduled inspection. Similarly, spent pebble fuel shipments may be verified at the HTGR or at the facility receiving the spent pebble fuel-depending on the verification method.

Regarding impact to the facility design, the IAEA inspector needs the ability to access and verify the fresh pebble fuel storage casks, vessels, and area and access hatches to the reactor core(s) and irradiated pebble fuel storage vessels to ensure that the containment and surveillance measures remain effective. They also need the capability to ensure that the fuel flow monitor can count, verify, and discriminate spent pebble fuel from fresh, used, and damaged pebble fuel and graphite moderator.

The facility design should also allow the inspector to safely service the installed seal, surveillance, and radiation-based fuel flow monitoring systems, and check the field of view of the surveillance cameras and radiation detectors. Typically, platforms and ladders are required for accessing and servicing the surveillance cameras, since the cameras may be placed at an elevated level in the reactor hall to cover the areas of interest.

If the IAEA is permitted by the facility operator and State Regulatory Authority to remotely monitor encrypted data from the seal, surveillance, and fuel flow monitoring systems, then the frequency of onsite inspections can typically be reduced - since the IAEA would be receiving most of the safeguards data continuously. In this case, the impact on facility operations is lessened, because of the decrease in field inspections. However, design provisions for seal, surveillance, and fuel flow monitoring systems are still required.

\section{Design Impacts (by Engineering Design Discipline)}

\section{i. $\quad$ Electrical/Instrumentation}

The electrical and instrumentation design engineers should provide for the power and associated cabling requirements for the IAEA safeguards equipment as specified by the IAEA. The following is based on IAEA practice to date, with consideration for the construction of larger and more complex pebble fuel HTGR anticipated in the near future. IAEA seal systems are battery powered and do not require external power. IAEA surveillance systems installed at an HTGR typically require facility mains power. Individual cameras require 2 amps or less @ 90 - 265 VAC (50-60 Hz). If a centralized surveillance data collection cabinet is used, it requires 30 amps per cabinet @ $90-265 \mathrm{VAC}(50-60 \mathrm{~Hz})$. The electrical components within the IAEA data collection cabinet have internal circuit breakers. If a radiation-based fuel flow monitoring system is used, its power requirements are comparable to those noted for the surveillance data collection cabinet. The number of data collection cabinets for the fuel flow monitoring system should be confirmed with the IAEA, because as many as three cabinets may be required. In the case of the surveillance and fuel flow monitoring system, the data collection system is computer server-based and requires a dedicated isolated electrical ground suitable for sensitive computing equipment. The IAEA surveillance and fuel flow monitor data collection cabinets should be connected to a facility emergency power circuit. These cabinets are also typically backed up by an IAEA provided UPS inside the cabinet. Cabling to and from the IAEA seal, surveillance, and fuel flow monitoring systems must meet IAEA tamper resistance specifications and is typically provided by the IAEA. If the seal, surveillance, or fuel flow monitoring systems are to be remotely monitored by the IAEA, they will specify other relevant requirements. The electrical power requirements for the fresh pebble fuel NDA systems and LCBS are typically 15 amps or less @ 100 - 230VAC $(50-60 \mathrm{~Hz})$. This can usually be provided by local convenience electrical power outlets. The electrical requirements for the 3DLR are comparable to those stated for the NDA systems. Under certain circumstances, these systems may require a $50 \mathrm{~m}$ electrical extension cord routed from the convenience electrical power outlet to the actual point of use (e.g. when using the 3DLR).

\section{ii. Mechanical}


The mechanical design engineer should provide for safe engineered access so the IAEA inspector can service the seal, surveillance, and fuel flow monitoring systems, and access the fresh pebble fuel storage area, fuel casks, and feed hoppers. Safe access should also be provided up to the access hatches to the reactor vessel and irradiated pebble fuel storage areas. Additional mechanical fixtures and modifications to the facility equipment may be required to permit use of the IAEA seal, surveillance, and fuel flow monitoring systems. These modifications are specified by the IAEA and may include, but are not limited to, the following:

- Modifications to the fresh pebble fuel shipping casks, drums, and feed hoppers to accommodate IAEA seals (e.g. modifications to the nuts, bolts, hasps, and lids to accommodate seal cables)

- Modifications to the access hatch covers to the reactor vessel and irradiated pebble fuel storage area to accommodate IAEA seals

- Modifications to the pebble fuel pneumatic transfer piping to permit the use of IAEA radiation detectors as part of a fuel flow monitoring system (e.g. detector wells and service boxes)

- Modifications to the facility operator's pebble fuel flow monitoring system, if used jointly with the IAEA (e.g. independent radiation detectors, wells, and service boxes)

- Fixed stanchions for mounting surveillance cameras, radiation detectors, and additional lighting

- Fixed platforms and ladders for servicing seals, surveillance cameras, and radiation detectors

- A hoist in the fresh pebble fuel storage area to raise fresh pebble fuel shipping casks or drums for verification

- Modifications to the spent pebble fuel shipping casks to accommodate IAEA seals

- A mechanical fixture for mating the Compton Dry-Cask Imaging System to the spent pebble fuel shipping casks

- Condensate drain(s) for the air conditioning system in the IAEA surveillance and fuel flow monitoring data collection cabinet(s).

\section{iii. Chemical/Analytical}

Not relevant to this facility type.

\section{iv. Industrial Safety}

The industrial safety design engineer should provide for safe engineered access so the IAEA inspector can service the seal, surveillance, and fuel flow monitoring systems, and access the fresh pebble fuel storage area, fuel casks, and feed hoppers. Safe access should also be provided up to the access hatches to the reactor vessel and irradiated pebble fuel storage areas. Design provisions for accommodating IAEA safeguards activities must not introduce other industrial hazards or risks.

\section{v. Radiation Safety and Health Physics}

The radiation safety design engineer should provide for safe engineered access so the IAEA inspector can service the seal, surveillance, and fuel flow monitoring systems, and access the fresh pebble fuel storage area, fuel casks, and feed hoppers. Safe access should also be provided up to the access hatches to the reactor vessel and irradiated pebble fuel storage areas. Radiation dose to the inspector must comply with as-low-as-reasonably-achievable (ALARA) radiation guidelines and practices for comparable work as performed by the facility operator and their staff. The re-verification of fuel in the reactor core and irradiated pebble fuel storage vessels should be in accordance with the facility operator's procedures and practices and must not result in excessive radiation exposure. Moveable shielding, respirators, or breathing air systems should be provided as necessary, to augment the designed radiation shielding and other safety features. 


\section{APPENDIX - EMERGING TECHNOLOGIES}

\section{Fresh Pebble Fuel Verification}

1. NDA techniques can be optimized for the verification of fresh (un-irradiated) pebble fuel. In the past, the IAEA has used a combination of gamma spectroscopy and active and passive coincident neutron counting systems (e.g. HRGS, MMCC, AWCC, and PNCL, etc.) to verify the nuclear material content of fresh LEU and MOX fuel. Since many of these systems depend on the measurement geometry and shape of the fuel, they will need to be optimized for pebble HTGR fuel. The technique used will also depend on the radionuclides present in the fresh fuel (i.e. plutonium, U-235, U-233, and thorium). Additionally, the designs of the pebble HTGR fuel are still evolving and it is important to realize that the fuel must be measured with greater accuracy if plutonium, HEU, and U-233 are present (i.e. typically $+/-2$ to $3 \%$ sigma for total $\mathrm{Pu}$ ).

\section{Containment and Surveillance}

2. New containment systems are being developed that could potentially replace or augment current IAEA seal systems. One of the challenges faced in using sealing systems is that they are difficult to apply to large numbers of containers (e.g. fresh pebble fuel casks) or hatch covers. To address this issue, a Remotely Monitored Sealing Array (RMSA) is being developed, which employs active electronic seals that use radio-frequency to communicate the seal status from multiple sealing points to a data collection system. ${ }^{25}$ In principle, this would eliminate the elaborate wire tying and daisychain cabling schemes that have been used in the past to seal large arrays of containers and reactor hatch covers. The RMSA is currently undergoing testing and evaluation by the IAEA, and is designed to remotely transmit the seal status and disposition to IAEA headquarters in Vienna or the nearest IAEA regional office. The data would be fully encrypted and the remote transmission subject to the approval of the facility operator and State Regulatory Authority.

3. Another system that could be used for monitoring a large array of fresh pebble fuel casks and reactor access hatch covers is the Laser-Based Item Monitoring System (LBIMS), a laser rastering system being developed at ORNL. ${ }^{26}$ This containment system would use fixed laser transmitter/receivers at the corners of the fresh pebble fuel storage area and reactor core(s) and would rapidly raster and scan the area. The fresh pebble fuel casks and reactor core hatch covers would have laser reflective tags for bouncing the rastered laser beams. If the fresh pebble fuel casks were moved, or hatch covers were opened, the system would note the missing bounce and record the date and time of the event. Such a system, used in conjunction with surveillance, would be more efficient and easier to service than dozens of seals applied to fresh pebble fuel drums and reactor access hatches. This system could also be used to monitor the access hatches to the PIE, used fuel, damaged fuel, and spent pebble fuel storage areas.

\section{Core and Spent Pebble Fuel Verification}

4. NDA techniques can be optimized for the verification of spent pebble fuel in storage. In this regard, it may be possible to use a system like the Compton Dry-Cask Imaging System being developed at INL to re-verify spent nuclear fuel in dry storage/transfer casks. ${ }^{23}$ This system detects and characterizes the Compton-scattering produced by the fission products in the spent fuel making a Compton map of the spent fuel storage/transfer cask. Such a map or fingerprint could permit the re-verification of spent pebble fuel in transfer/storage casks, after an initial verification is performed (i.e. after the reference Compton image for the cask is created). 
5. To re-verify the core pebble fuel in the reactor vessel and associated pebble fuel storage vessels, it is possible to design and construct interrogation wells adjacent to the vessels that would allow the IAEA to insert radiation detectors from a number of available gamma and neutron NDA instruments. In this case, it would be possible for the IAEA to raise the gamma/neutron radiation detectors to verify the attributes of the bulk irradiated fuel and confirm the vessel fill-height or volume. One drawback in this case, is the additional cost of engineering and constructing interrogation wells adjacent to the aforementioned vessels. This underscores the importance of the facility designer, operator, and State Regulatory Authority confirming how the IAEA plans to verify the irradiated pebble fuel in the reactor core and associated storage vessels. Instrument interrogation wells are used in safeguarding MOX fuel fabrication and spent fuel reprocessing plants. The design and construction is feasible, albeit more costly.

6. Historically, the IAEA has used the facility operator's instruments and operating records to confirm the declared period of operation of the reactor and irradiation of the core fuel. They also use the relevant nuclear fuel burn-up code to corroborate the facility operator's calculation of the radionuclide content of the core fuel upon discharge from the reactor and transfer to spent fuel storage. There are presently, very few pebble fuel HTGR in operation. Consequently, there is scant data for performing the relevant nuclear fuel burn-up modeling calculations. To address this need, an optimized version of a nuclear fuel burn-up code (such as ORIGEN) could be adapted, supported by irradiation studies with pebble fuel of the relevant design.

7. The use of anti-neutrino detectors embedded below or to the side of the core has been suggested for independently verifying the duration of reactor operation and fuel burn-up in nuclear reactor cores. ${ }^{27}$ The technology appears amenable for verifying HTGR cores as well. Because the pebble fuel HTGR core fuel would be considered "difficult to access," the incentive for using anti-neutrino detectors in this case is more compelling than in a case where the reactor core is more easily accessed (i.e. LWR core during annual refueling). The additional cost is an issue, although it is feasible, and would provide completely independent verification of the burn-up of the reactor core fuel and period of irradiation.

8. Overhead satellite thermal imagery could be used to confirm the declared period of operation of the pebble fuel HTGR core(s). Commercially available satellite imagery, including thermal/infrared, is available as a tool to verify the operator's declared period of reactor operation. In such a case, the facility could be designed to maximize the visible process heat signature from each reactor core. However, one must also consider that satellite imagery for a specific reactor location may not always be available. Regardless, in cases where there is an important need to confirm the reactor period of operation, the use of overhead thermal imagery remains viable and affordable.

\section{Pebble Fuel Transfer Cask Monitoring and Tracking}

9. The containment of fresh and spent pebble fuel in transfer casks could be dramatically improved if so-called "smart" transfer casks were developed, especially for pebble fuel containing direct-use nuclear material (i.e. plutonium, HEU, or U-233). Such casks would have tamper indicating and monitoring/tracking features integrated directly into the cask design. These features could be an addon package or be integrated into the cask construction. The data monitored could include the cask serial number, lid status (open or closed), radiation field near the lid, GPS coordinates, cask motion or speed, etc. The monitoring and tracking data could also potentially be remotely transmitted. If the data were transmitted to the State Regulatory Authority and IAEA, these organizations would know in real-time the status, disposition, and location of the fresh and spent pebble fuel in transit. Radiofrequency monitoring and tracking systems have been developed for $\mathrm{UF}_{6}$ cylinders, as sponsored by U.S. DOE NNSA. ${ }^{28}$ The results from this research and development could also be adapted to the tracking and monitoring of fresh and spent pebble fuel in transit, especially for pebble fuel containing direct-use material. 


\section{In-situ Design Verification}

10. Because of the number of pebble fuel storage vessels and complexity of the fuel transfer paths, it may be possible to design elements in the facility for in-situ verification of the safeguards relevant design features. These could include provisions that would allow the IAEA to verify the routing of pebble fuel pneumatic transfer piping, and location, number, and size of pebble fuel storage vessels. The LBIMS or RMSA could potentially be used to ensure that key areas have not been accessed, and hence altered. Pre-installed load cells or vessel (capacitance or current) fill-height instruments could be used to verify the mass or fill-height of the pebble fuel storage vessels. These instruments could be used to verify the volume or mass of the fuel stored, as well as for verifying the volume or mass of vessels remaining empty to ensure that they have not been enlarged or replaced. It may also be possible to install high radiation hot-cell viewing windows for using the 3DLR to re-verify the design and construction of complex pebble fuel pneumatic transfer pipe routes and connections. Although it may not be practical to provide $100 \%$ coverage of the piping in the high radiation area, it may be possible to provide shielded hot cell windows that view onto the primary pebble fuel storage vessels and pebble fuel pneumatic pipe routes. 


\section{REFERENCES}

1. International Atomic Energy Agency: The Safeguards System of the International Atomic Energy Agency, Vienna, Austria, ca. 2011; from: http://www.iaea.org/OurWork/SV/Safeguards/documents/safeg_system.pdf.

2. International Atomic Energy Agency: Board of Governors Document, GOV/2554/Attachment2/Rev.2, Vienna, Austria, 1992.

3. U.S. Department of Energy, U.S. Nuclear Regulatory Commission: Next Generation Nuclear Plant Licensing Strategy - A Report to Congress, Washington, D.C., August, 2008.

4. U.S. DOE Idaho National Laboratory: Next Generation Nuclear Plant, Idaho National Laboratory Website, updated April 12, 2011; from http://www.nextgenerationnuclearplant.com/facility/index.shtml.

5. International Atomic Energy Agency: Status and Prospects for Gas-Cooled Reactors, IAEA Technical Report Series No. 235, Vienna, Austria, 1984.

6. International Atomic Energy Agency: International Status of HTGRs, IAEA Bulletin Vol. 26, No. 4, Vienna, Austria, 1984.

7. Sedov, A.: Development of HTGR Technologies in Russia: Experience, Activities, and Plans, RRC Kurchatov Institute Paper, Presented at Villigen PSI, November, 2009.

8. Dulera, I.V., Sinha, R. K.: The Indian High Temperature Reactor Programme, International Conference on Non-Electric Applications of Nuclear Power, Paper IAEA-CN-152-20, Oarai, Japan, April, 2007.

9. Next Big Future: Areva Antares Prismatic Modular Reactor Selected for Next Generation Nuclear Plant (NGNP), Next Big Future on-line magazine, Feb. 18, 2012; from:

http://nextbigfuture.com/2012/02/areva-anteres-prismatic-modular-reactor-selected-for-nextgeneration-nuclear-plant/

10. Slabber, J.: PBMR Nuclear Material Safeguards, PBMR (Pty) Ltd., Paper \#B14, Presented at the $2^{\text {nd }}$ International Topical Meeting on High Temperature Reactor Technology, Beijing, China, September, 2004.

11. Japan Atomic Energy Agency: High Temperature Engineering Test Reactor (HTTR), Information Sheet (English), ca. 2011; from http://http.jaea.ogoljp/eng/index.html

12. International Atomic Energy Agency: The Structure and Content of Agreements between the Agency and States Required in Connection with the Treaty on the Non-Proliferation of Nuclear Weapons, INFCIRC/153 (corrected), Vienna, Austria, June, 1972.

13. International Atomic Energy Agency, Department of Safeguards: Safeguards Manual, Parts- SMI and SMC, Section SMC-3, "Other Types of Reactors," Vienna, Austria, October, 2003; (IAEA Internal Document, incorporated into the IAEA Quality Management System (QMS) ca. 2009).

14. International Atomic Energy Agency, Department of Safeguards: Safeguards Manual, Parts- SMI and SMC, Section SMC-14, Annexes, Vienna, Austria, October, 2003; (IAEA Internal Document, incorporated into the IAEA Quality Management System (QMS) ca. 2009).

15. International Atomic Energy Agency: IAEA Safeguards Glossary-2001 Edition (para. 3.5), Vienna, Austria, 2002. 
16. Bjornard, T. A., et al.: Implementing Safeguards-by-Design, U.S. DOE Idaho National Laboratory Report, INL/EXT-09-17085, Idaho Falls, Idaho, February, 2010.

17. Slabber, J.: PBMR Nuclear Material Safeguards, PBMR (Pty.) Ltd. Paper \#B14, $2^{\text {nd }}$ International Topical Meeting on High Temperature Reactor Technology, Beijing, China, September, 2004.

18. Durst, P. C., et al.: Nuclear Safeguards Considerations for the Pebble Bed Modular Reactor (PBMR), U.S. DOE Idaho National Laboratory Report, INL/EXT-09-16782, Idaho Falls, Idaho, October, 2009.

19. International Atomic Energy Agency, Department of Safeguards: Safeguards Techniques and Equipment: 2011 Edition; International Nuclear Verification Series \#1 (Rev.2), Vienna, Austria, 2011.

20. Canberra/AREVA: Safeguards Equipment Data Sheets, Canberra USA, Albuquerque, New Mexico, USA, November, 2006 and 2011.

21. Zendel M., Moeslinger, M.: IAEA Safeguards Equipment, Presentation at the Conference on Advanced Sensors for Safeguards, Santa Fe, New Mexico, USA, April, 2007.

22. Moeslinger, M., et al.: The IAEA's XCAM Next Generation Surveillance System, International Nuclear Safeguards Symposium, Paper IAEA-CN-184/260, Vienna, Austria, November, 2010.

23. U.S. DOE Idaho National Laboratory: Compton Dry-Cask Imaging System, Idaho National Laboratory R\&D Technology - 2011, Fact Sheet; from http://www.inl.gov/rd100/2011/compton-drycask-imaging-system/

24. Zoller and Froehlich GmbH: Imager 5006 (3DLR) User Manual, Version 1.0.5, (English), Wangen im Allgaeu, Germany, ca. 2011.

25. Durst, P. C.: Personal Communication with Marius Stein of Canberra/AREVA, Regarding the Development of the RMSA, March, 2011.

26. Laughter, M.: Safeguards Application Options for the Laser-Based Item Monitoring System (LBIMS), U.S. DOE Oak Ridge National Laboratory Report, ORNL/TM-2008/086, Oak Ridge, Tennessee, October, 2008.

27. Bernstein, A., et al.: Nuclear Security Applications of Anti-Neutrino Detectors: Current Capabilities and Future Prospects, Science and Global Security, Routledge, Taylor, and Francis Group, 18:127$192,2010$.

28. Pickett, C., et al.: Results from a Proof-of-Concept Demonstration of RF-Based Tracking of UF 6 Cylinders during Process Operations at a Uranium Enrichment Plant, Proceedings of the INMM Annual Meeting, Nashville, Tennessee, July, 2008. 